\title{
The modern pollen-vegetation relationship in Jammu, India: a comparative appraisal
}

\author{
MD. FIROZE QUAMAR*, POOJA TIWARI and BISWAJEET THAKUR \\ Birbal Sahni Institute of Palaeosciences, Lucknow-226007, India; e-mail: quamar_bot@yahoo.co.in, \\ mohdfiroze_quamar@bsip.res.in
}

Received 8 August 2020; accepted for publication 17 March 2021

\begin{abstract}
An understanding of the relationship between modern pollen and vegetation is a prerequisite for reconstruction of vegetation and climate change from fossil pollen records. We conducted palynological studies of thirty-five surface soil samples from the Jammu region of India, which revealed that Pinus, among the conifers (regional needle-leaved taxa), is over-represented in the pollen assemblage due to its high production and effective dispersal of pollen. Other coniferous and broadleaved (regional and/or extra-regional) taxa have comparatively lower values in the pollen assemblages, similar to the representation of subtropical deciduous forest elements (regional), as well as shrubby (regional and/or extra-regional) taxa. This inconsistency in the pollen assemblage could be due to long-distance transport of the former by wind and/or water from the higher reaches of the Himalayas, and also because the latter have an entomogamous pollination syndrome and are not high pollen producers. The recovered pollen assemblage presents a distorted picture of the extant vegetation; hence, caution should be exercised in interpreting fossil pollen records from the study area. Principal component analysis (PCA) shows variability in the distribution of pollen from different sites in the Jammu region, perhaps the result of transport (by wind and/ or water), altitude and/or edaphic factors of the Himalayan terrain. The study should improve our understanding of the modern pollen-vegetation relationship and aid further calibration and interpretation of fossil pollen records.
\end{abstract}

KEYWORDS: Palynology, surface soil, vegetation and climate change, PCA, Jammu (India)

\section{INTRODUCTION}

An adequate understanding of the relationship between modern pollen assemblages and extant vegetation is needed for the confident use of fossil pollen records for reconstruction of vegetation and climate change (Moore and Webb, 1978; Faegri and Iversen, 1989; Birks and Berglund, 2018; Quamar and Kar, 2020 and references cited therein). However, the Fagerland effect (non-linearity of the modern pollen-vegetation relationship, i.e. there is no one-to-one relationship between modern pollen and extant vegetation; Fagerland, 1952) twists the basic assumption of that relationship. Furthermore, the uncertainties related with pollen production, dispersal and preservation of taxa of angiosperms and gymnosperms, the structure

\footnotetext{
Corresponding author
}

of the surrounding vegetation, and taxonomic resolution of pollen (Faegri and Iversen, 1964; Quamar and Bera, 2014a-c; Gaceur et al., 2017; Broothaerts et al., 2018; Bajpai and Kar, 2018; Quamar, 2020; Quamar and Kar, 2020 and references therein) add to the complexity of the problem. That non-linearity, taphonomic issues, and differential pollen production result in pollen percentages that are ambiguously related to the abundance of the corresponding plant species in the vegetation. Understanding that relationship and the accompanying uncertainties are key to interpreting the fossil pollen data, and can improve the quality of reconstructions and interpretations of past vegetation, landscape and climate (Chen et al., 2017). Much research on that relationship has been done on the Indian subcontinent in the most recent 
years (Quamar and Bera, 2014a, 2017; Quamar, 2017; Quamar and Kar, 2020 and references cited therein), but fewer such studies have been done in the Jammu region (Vishnu-Mittre and Robert, 1971; Sharma et al., 2001; Quamar and Srivastava, 2013; Quamar et al., 2018a, b; Quamar, 2020). To address this, we analysed the pollen of 35 surface soil samples in order to establish the relationship between extant vegetation and the modern pollen assemblage, and to provide data on the modern pollen-vegetation relationship useful for improving the interpretation of fossil pollen records from the Indian subcontinent on different spatio-temporal scales. The selected sites have not been previously studied in terms of modern pollen dispersal or palaeoclimate reconstruction. A modern analogue of the pollen-vegetation relationship should help us understand the dynamics of vegetation and climate in and around the study area. We compare our present inferences on the pollen-vegetation relationship from Ranbir Singh Pura, Bajalta and Samba in the Jammu region with recently published records from the same region (Akhnoor in Jammu District: Quamar, 2020; Udhampur District and Reasi District: Quamar et al., 2018a, b, respectively).

\section{STUDY AREA, GEOLOGY AND SOIL}

Ranbir Singh (R.S.) Pura Sector ( $32^{\circ} 36^{\prime} 51.52^{\prime \prime}$ $\mathrm{N}, 74^{\circ} 38^{\prime} 58.15^{\prime \prime} \mathrm{E}$; $281 \mathrm{~m}$ a.s.l.) is located about $45 \mathrm{~km}$ southwest of Jammu Township, and Bajalta village is situated about $18 \mathrm{~km}$ northwest of Jammu Township $\left(32^{\circ} 45.621^{\prime} \mathrm{N}\right.$, $74^{\circ} 57.026^{\prime} \mathrm{E}$; $390 \mathrm{~m}$ a.s.l.) in Jammu District. Samba District $\left(32^{\circ} 33^{\prime} 15.44^{\prime \prime} \mathrm{N}, 75^{\circ} 06^{\prime} 55.70^{\prime \prime} \mathrm{E}\right.$; $384 \mathrm{~m}$ a.s.l.) is about $47 \mathrm{~km}$ southeast of Jammu Township in the Jammu region (Figs 1 and 2). The landscape of the Jammu region is mainly plain to the south of the Siwalik hills. The lesser Himalayan Mountains are found northwards up to the Pir Panjal range. An intricate mosaic of mountain ranges and hills lies around the study areas, with river terraces, valleys and gorges (Mir, 2003). Silt deposits dominate in the northeast (Ravi Basin) and the northwest (Chenab Basin) of the Jammu foothills, which suggests transport (Wiggs, 1997; Ganjoo and Kumar, 2012) under reduced flow along river channels/banks (Chakrapani, 2005). These alluvial soils have little clay content, and stony and sandy soils are the chief soil types around the study areas (Mir, 2003), supporting cultivation of crops there.

\section{VEGETATION}

The plant life around the Jammu region is generally rather diverse, comprising 506 species of angiosperms, gymnosperms and pteridophytes (Pandita et al., 2014), including 86 herbaceous species and 62 genera of 29 tree and shrub families. Of the recorded species, 19 species of Fabaceae, 8 species of Malvaceae, 5 species each of Rosaceae and Rutaceae, and 6 species each of Moraceae and Euphorbiaceae have been identified. Seventeen families are monogeneric and monospecific: Phyllanthaceae, Salicaceae, Vitaceae, Arecaceae, Musaceae, Bignoniaceae, Capparaceae, Oleaceae, Boraginaceae, Lamiaceae, Cucurbitaceae, Puniaceae, Caricaceae, Asclepidiaceae, Moringaceae, Verbinaceae and Rubiaceae. Subtropical pine forests, lower Siwalik Chirpine (Pinus roxburghii) forests, subtropical dry evergreen forests, Himalayan moist temperature forests, Himalayan dry temperature forests, and sub-alpine and moistalpine forests form the vegetation of the Jammu region. Subtropical dry mixed deciduous forests represent the vegetation type of the Jammu plains. Shrub-forest dominates the submontane and semimontane zones of the study areas. In the outer hills the flora differs entirely from the middle mountains, sub-mountainous and semi-mountainous zones with Deodar (Cedrus libani) as the dominant tree species (Champion and Seth, 1968; Sharma and Kachroo, 1981; Singh et al., 2002; Mir, 2003). Table 1 shows the accompanying species of the forests in and around the Jammu region (Quamar, 2020).

\section{CLIMATE}

The Jammu region has a monsoon-influenced subtropical humid climate (Cwa) (Köppen, 1936). The southwest monsoon (a component of Indian Summer Monsoon; ISM) brings rains during the months of June-September in the foothills and the Siwalik Range of the Jammu region. The area receives some precipitation during the winter months of December, January and February due to the Western Disturbances (WDs). The nearest climate research unit timeseries (CRU TS; 4.01, $0.5 \times 0.5$ gridded 


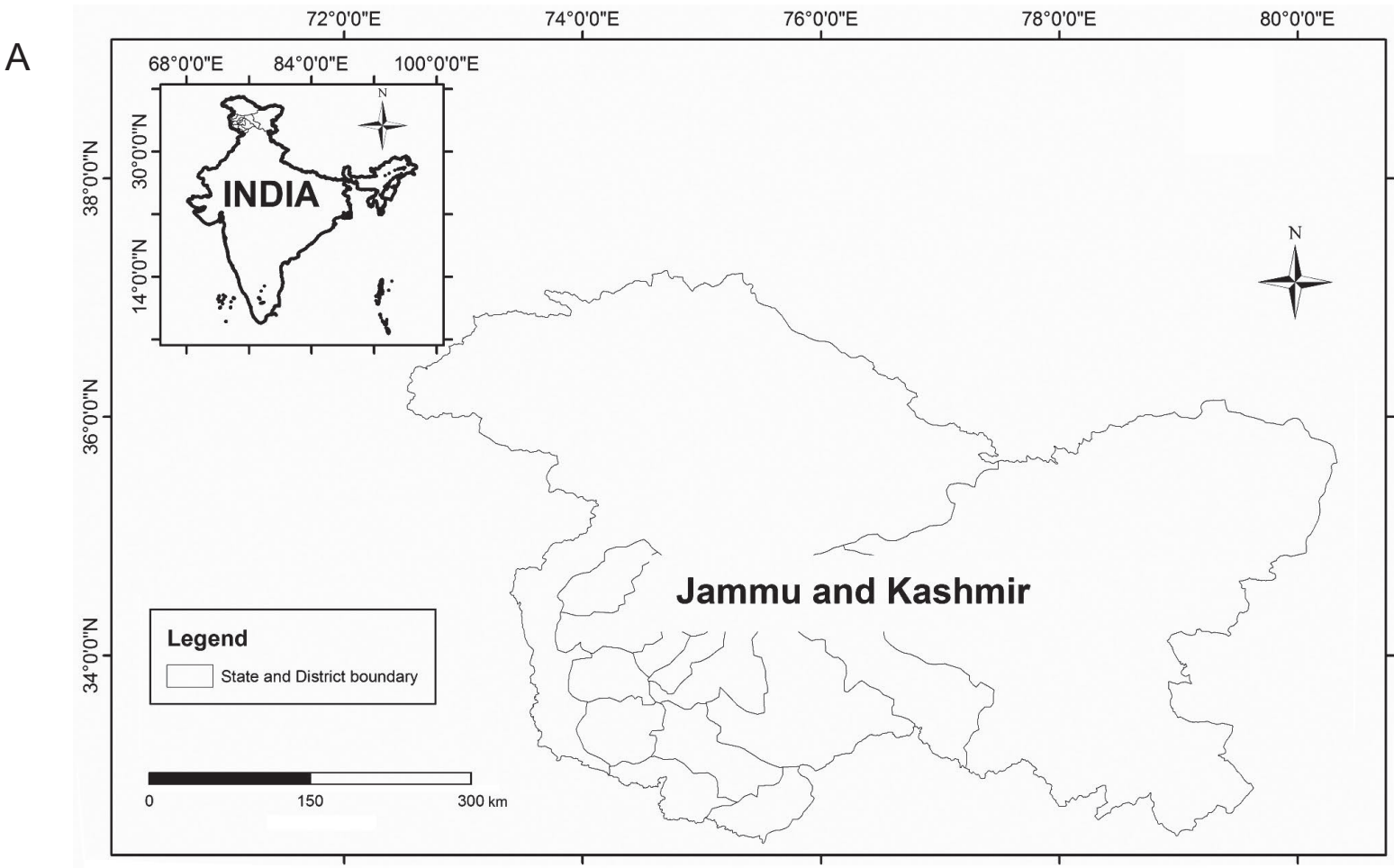

B

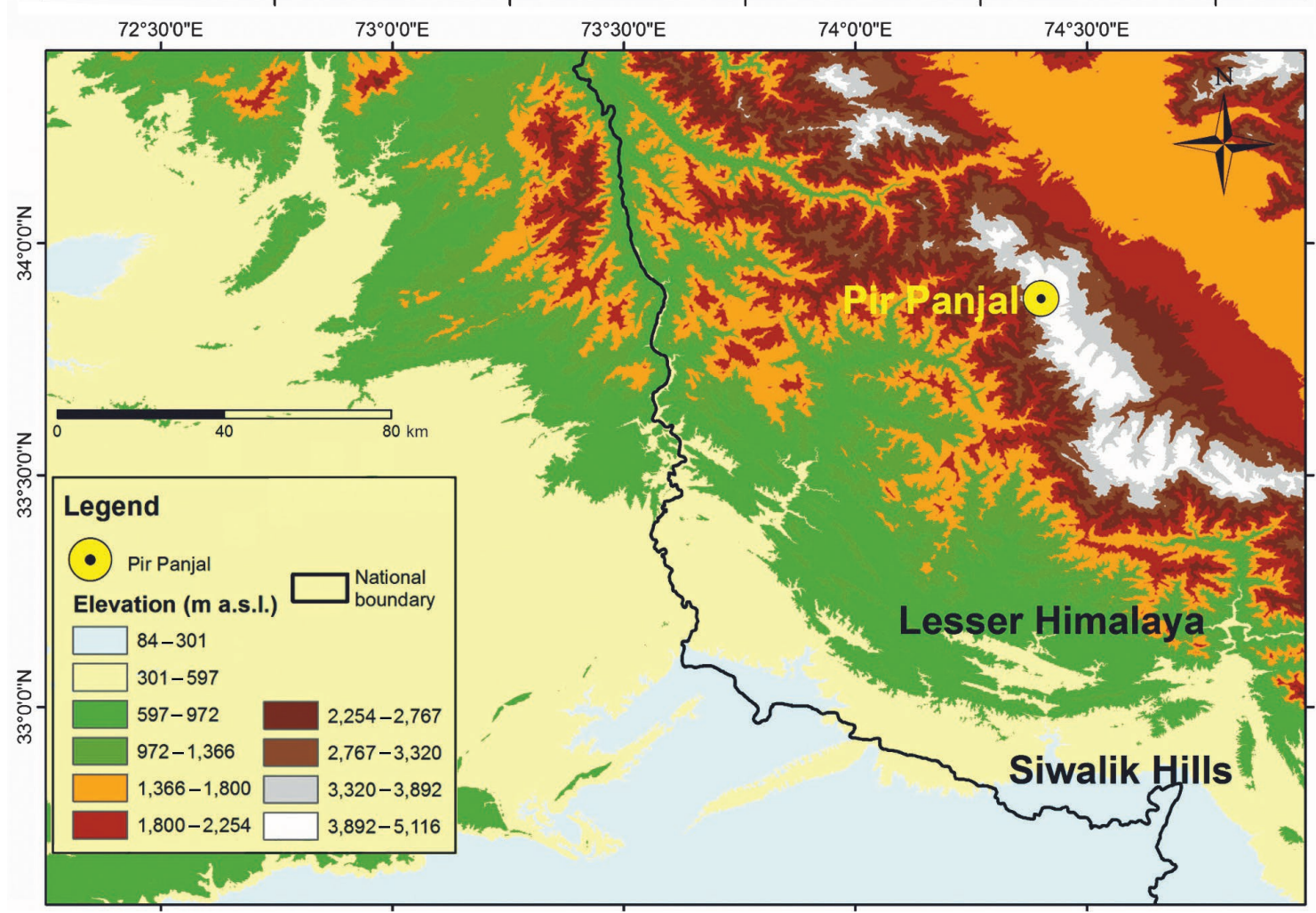

Fig. 1. A. Geographic map of India showing Jammu and Kashmir State. B. Shutter radar topographic mission (SRTM) digital elevation map (DEM) of Jammu District (Jammu and Kashmir State, India), showing Pir Panjal range (yellow circle), Siwalik Hills and Lesser Himalaya. Source of Figure 1: created using ArcGIS 10.3.

climate data points, 1901-2016) shows mean monthly precipitation and temperature around the study areas of Jammu region (Harris et al., 2014) (Fig. 3; Supplementary file $1^{1}$ ).

1 Supplementary file 1: Temperature and precipitation records (monthly) during 1901-2016 from the study areas
Mean annual temperature (MAT) is $23.73^{\circ} \mathrm{C}$ for Jammu District and $21.55^{\circ} \mathrm{C}$ for Samba District of the Jammu region. Mean annual precipitation (MAP) is $755.28 \mathrm{~mm}$ for Jammu District and $899.75 \mathrm{~mm}$ for Samba District. Wind speed also plays a pivotal role around the study areas. 


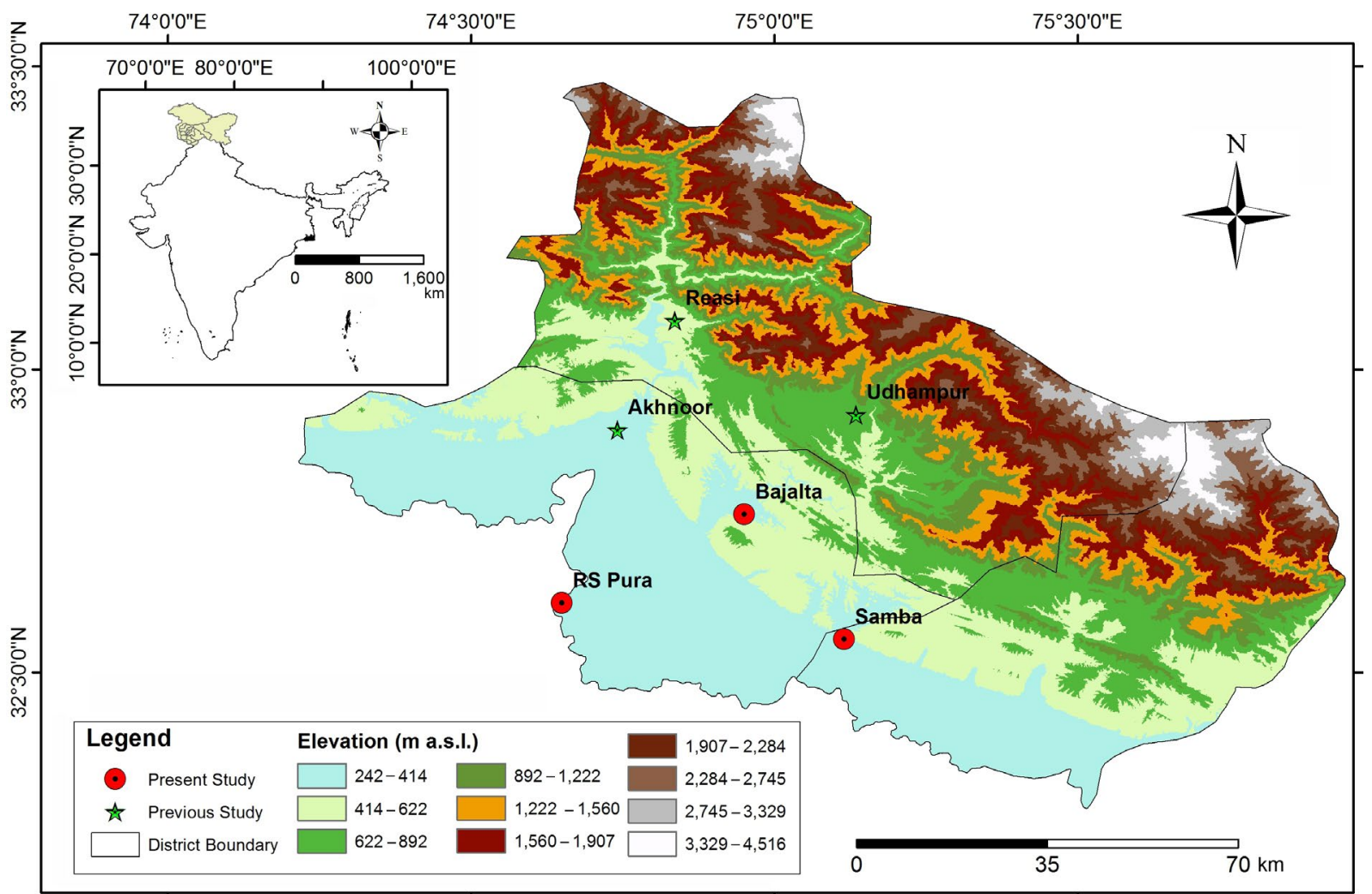

Fig. 2. Geographic map of India showing Jammu and Kashmir State (inset left). Shutter radar topographic mission (SRTM) digital elevation map (DEM) of Jammu District (Jammu and Kashmir State, India) showing the present study sites (R.S. Pura, Bajalta village in Jammu District, Samba District; red circles). Akhnoor (Jammu District), Udhampur and Reasi districts are given on the map to show the location of the recently published records (star) that are compared with the present study. Source of Figure 2: created using ArcGIS 10.3.

Table 1. Vegetation (regional taxa as well as extra-regional taxa) of the Jammu region, Jammu and Kashmir, India

\begin{tabular}{|c|c|c|}
\hline \multicolumn{2}{|c|}{ Arboreal taxa (trees and shrubs) } & Non-arboreal taxa (herbaceous taxa) \\
\hline $\begin{array}{r}\text { Subtropical } \\
\text { (Regiona }\end{array}$ & $\begin{array}{r}\text { Temperate for } \\
\text { ments (Extra } \\
\text { shru }\end{array}$ & $\begin{array}{l}\text { Terrestrial h } \\
\text { Poaceae (Gr }\end{array}$ \\
\hline $\begin{array}{l}\text { Conifers: } \\
\text { Pinus sp. (Pinus roxburghii) } \\
\text { Broad-leaved taxa: } \\
\text { Ulmus sp., Juglans sp., Quercus sp. } \\
\text { Sub-tropical deciduous tree taxa: } \\
\text { Mallotus sp., Fraxinus sp., Sho- } \\
\text { rea sp., Bombax sp., Syzygium } \\
\text { sp., Mimosaceae, Emblica off- } \\
\text { cinalis, Terminalia spp., Ficus } \\
\text { spp., Grewia sp., Tamarindus sp., } \\
\text { Mitragyna parvifolia, Lannea cor- } \\
\text { omandelic, Acacia catechu, Butea } \\
\text { monosperma, Mallotus philippen- } \\
\text { sis, Albizzia sp., Eucalyptus sp., } \\
\text { Bombax ceiba, Dalbergia sissoo, } \\
\text { Morus alba, Cedrela toona, Melia } \\
\text { azedarach, Bauhinia variegata, } \\
\text { Flacourtia indica, Azadirachta } \\
\text { indica, Ailanthus excelsa, Acacia } \\
\text { modesta, Cassia fistula, Phoenix } \\
\text { sylvestris, Olea sp., Sapindus sp. } \\
\text { Sub-tropical deciduous shrubby } \\
\text { taxa: } \\
\text { Acanthaceae, Rungia sp., Ziziphus } \\
\text { sp., Strobilanthes sp. }\end{array}$ & $\begin{array}{l}\text { Conifers: } \\
\text { Pinus spp. (Pinus gerardiana, } \\
\text { P. wallichiana), Cedrus sp., Abies } \\
\text { sp., Picea sp., Larix sp., Podocar- } \\
\text { pus sp., Juniperus sp., Tsuga sp. } \\
\text { Broad-leaved taxa: } \\
\text { Alnus sp., Betula sp., Carpinus } \\
\text { sp., Corylus sp., Acer sp., Ilex sp., } \\
\text { Salix sp., Aesculus sp., Celtis sp., } \\
\text { Rhododendron sp., Skimmia sp. } \\
\text { Alpine scrub/Shrub: } \\
\text { Ephedra sp. } \\
\text { Tropical, sub-tropical and warm } \\
\text { temperate (Shrubby taxa): } \\
\text { Dodonea } \text { sp., Croton sp. }\end{array}$ & $\begin{array}{l}\text { Cerealia, Amaranthaceae, Caryophyllaceae, Brassica- } \\
\text { ceae, Artemisia sp., Alternanthera sp., Cannabis sativa, } \\
\text { Plantago sp., Urticaceae, Rumex hastatus } \\
\text { Heathland taxa: } \\
\text { Asteroideae/Tubuliflorae and Cichorioideae/Liguliflorae } \\
\text { (Asteraceae family), Malvaceae, Xanthium sp., Jus- } \\
\text { ticia sp., Aconitum sp., Oldenlandia sp., Mimosaceae, } \\
\text { Boraginaceae, Potentilla sp., Ricinus communis, Vitex } \\
\text { negundo, Lantana camara, Parthenium hysterophorus, } \\
\text { Datura metel, Murraya koenigi, Nerium indicum, Agave } \\
\text { americana, Colebrookia oppositifolia, Euphorbia sp., } \\
\text { Punica granatum, Ipomoea sp., Jasminum officinale, } \\
\text { Cynodon dactylon, Saccharum munja, Dioscorea sp., } \\
\text { Abrus precatorius, Vetiveria zizanoides } \\
\text { Marshy/Wetland taxa: } \\
\text { Cyperaceae (Sedges), Polygonum plebeium, P. serrula- } \\
\text { tum, Pimpinella sp., Polygala sp., Hygrophila sp., Chro- } \\
\text { zophora sp., Solanum sp. } \\
\text { Aquatic taxa: } \\
\text { Potamogeton sp., Lemna sp., Typha sp., Utricularia sp., } \\
\text { Nymphoides sp. (Nymphaeaceae) } \\
\text { Algae: Zygnema sp., Spirogyra sp., Botryococcus sp., } \\
\text { Pediastrum sp., Pseudoschizaea sp. } \\
\text { Pteridophytic taxa: } \\
\text { Dryopteris sp., Adiantum sp., Diplazium sp., Selaginella } \\
\text { sp., Lycopodium sp. }\end{array}$ \\
\hline
\end{tabular}




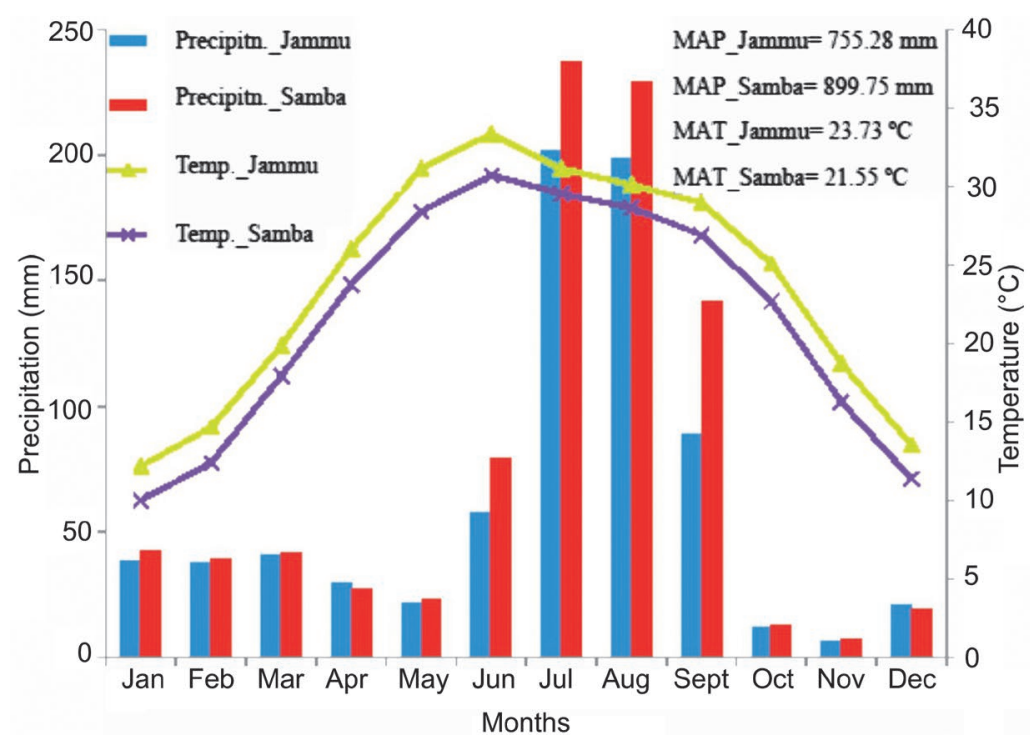

Fig. 3. Nearest Climate Research Unit Timeseries (CRU TS) 4.01, $0.5 \times 0.5$ gridded climate data point, 1901-2016, showing mean monthly precipitation and temperature around the study areas in the Jammu region of Jammu and Kashmir, India. These data are 116-year climate averages for the period 1901-2016; MAP - mean annual precipitation; MAT - mean annual temperature

\section{MATERIALS AND METHODS}

We collected 35 modern soil samples along a linear transect at varying intervals of $\sim 150-300 \mathrm{~m}$ from open areas of R.S. Pura and Bajalta village (Jammu District) and Samba District of the Jammu region (Jammu and Kashmir), India, in February 2015. The samples were collected manually with a spatula into ziplock polythene bags, when it had been raining for the previous few days. The surface samples were taken down to $0.5 \mathrm{~cm}$ depth after removing any grass from the sampling sites.

Extraction of palynomorphs from the modern surface soil samples followed the standard preparation procedures devised by Erdtman (1943). In the chemical treatments, $10 \mathrm{~g}$ each of the 35 samples were boiled with $10 \% \mathrm{KOH}$ to remove humus. Then the samples were treated with $40 \% \mathrm{HF}$ and an acetolysis mixture (9:1 mixture of acetic anhydride $\mathrm{C}_{4} \mathrm{H}_{6} \mathrm{O}_{3}$ and concentrated sulphuric acid $\mathrm{H}_{2} \mathrm{SO}_{4}$ ) to remove the silica, pollen kit, protoplasm and other cellulosic material. Five $\mathrm{ml}$ of $50 \%$ glycerine solution was added to the treated residue for microscopic examination and further storage, and $2 \mathrm{ml}$ phenol was also added to avoid any postmaceration microbial contamination.

The palynomorphs were counted under a transmitted light microscope (Olympus BX50) with a 40x objective at the Quaternary Palynology Laboratory of the Birbal Sahni Institute of Palaeosciences (BSIP), Lucknow, India. Pollen and spores were identified by comparing their morphological characters with pollen and spores in published literature (Nair, 1965; Gupta and Sharma, 1987; Nayar, 1990; Quamar and Srivastava, 2013; Quamar, 2019; Quamar and Stivrins, 2021) and the pollen reference collection at the sporothek of the BSIP Herbarium. The samples were not very productive, though we tried to reach total pollen counts of $\sim 300$ per sample. Pollen percentages were, however, calculated using the total pollen sum of the terrestrial plant pollen. We excluded pollen of aquatic plants, marshy (wetland) taxa, as well as spores of algae, ferns and fungi, from the total pollen sum, but calculated their percentages using the total pollen sum. The pollen spectra (Figs 4-6) were combined into histograms (Supplementary File 2) using TILIA software (Grimm, 1990). Taxa in the pollen spectra were grouped as trees, shrubs, terrestrial herbs, marshy (wetland) taxa, aquatics, algal remains, pteridophytic taxa and fungal spores.

To assess the differences in pollen counts between study sites, we applied principal component analysis (PCA), using CANOCO ver. 5.0. PCA is an unconstrained method for reducing the dimensionality of large datasets, giving increasing interpretability and also minimizing information loss (Jolliffe and Cadima, 2016). PCA reduces the eigen value/eigenvector problem in data analysis. For the present study, we chose PCA as a vital predictive technique to differentiate the pollen distributions over varying geographical sites with different environmental constraints.

\section{RESULTS}

\section{FROM OPEN AREAS OF R.S. PURA, JAMMU DISTRICT}

The fifteen surface samples collected from open areas of the R.S. Pura Sector of Jammu District (Fig. 2) showed higher frequency of conifers (needle-leaved taxa) than of broadleaved taxa among the arboreal pollen (AP) taxa. The non-arboreal pollen (NAP) taxa reached fairly high values in the total pollen rain (Fig. 4; Supplementary file $2^{2}$ ). Table 2 presents detailed palynological results from this area. In PCA, $68 \%$ of the total variance of the data on dominant

2 Supplementary file 2: Raw data (pollen counts) from R.S. Pura and Bajalta areas of the Jammu District, as well as from the Samba District of Jammu region 


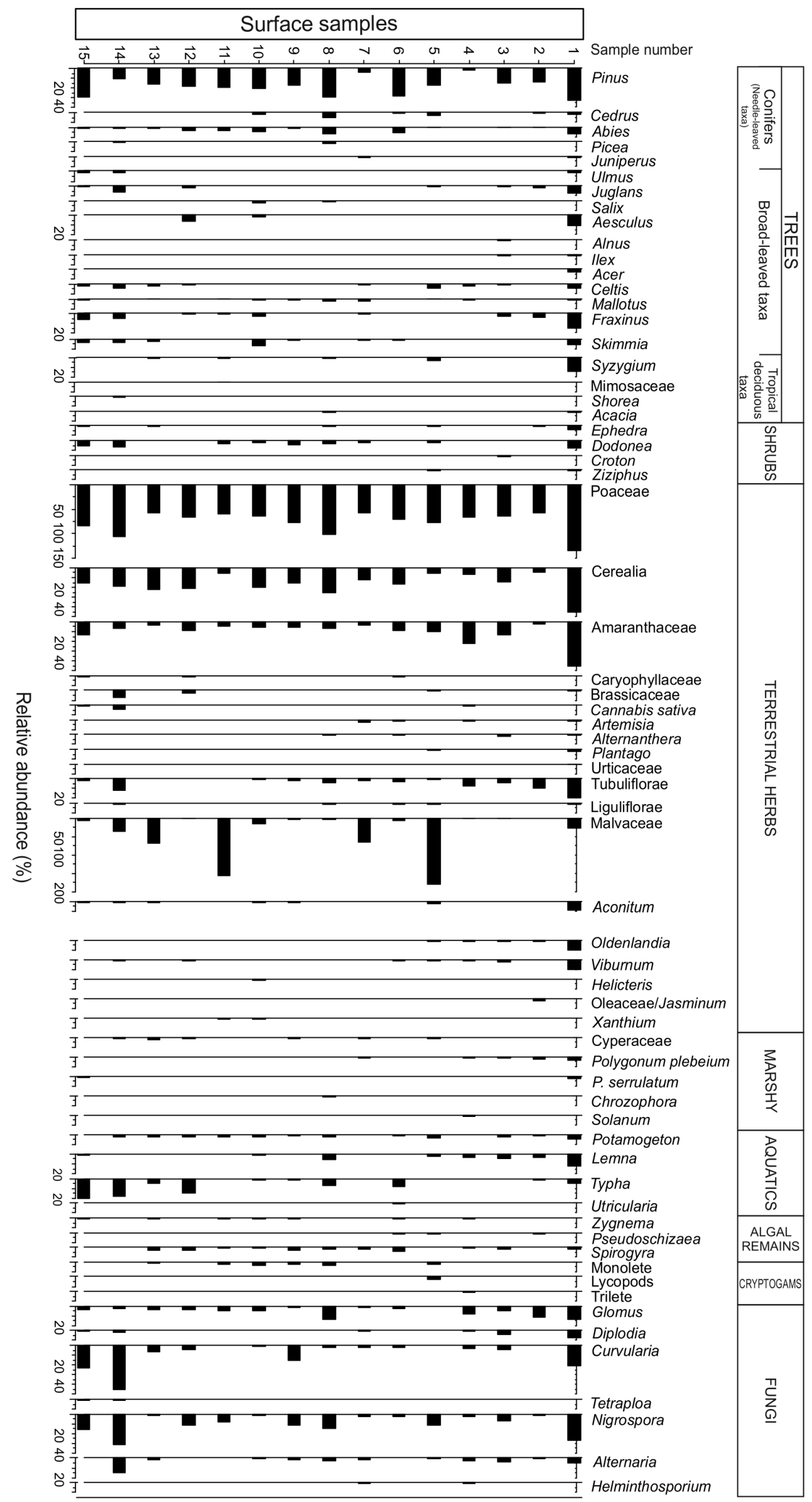

Fig. 4. Modern pollen spectra from open areas of R.S. Pura, Jammu District, Jammu and Kashmir, India 
Table 2. Palynological results from the Jammu region; see Materials and Methods for explanation of percentages

\begin{tabular}{|c|c|c|}
\hline $\begin{array}{l}\text { Open areas of R.S. Pura, } \\
\text { Jammu District }\end{array}$ & $\begin{array}{c}\text { Open areas of Bajalta village, } \\
\text { Jammu District }\end{array}$ & Open areas of Samba District \\
\hline $\begin{array}{l}\text { Conifers (10.32\%): Pinus sp. (mean } 8.49 \%) \text {, } \\
\text { Cedrus sp., Abies sp., Picea sp., Juniperus } \\
\text { sp. (mean } 1.82 \%) \text {, sporadic. }\end{array}$ & $\begin{array}{l}\text { Conifers (mean 16.35\%): Pinus sp. } \\
\text { (mean 14.74\%); Cedrus sp., Juniperus } \\
\text { sp. (mean 1.61\%), sporadic. }\end{array}$ & $\begin{array}{l}\text { Conifers (mean } 10.17 \%) \text { : Pinus sp. } \\
\text { (mean } 10.08 \%) ; \text { Cedrus sp., Picea sp., } \\
\text { Larix sp., Juniperus sp. (mean 1\%), } \\
\text { sporadic. }\end{array}$ \\
\hline $\begin{array}{l}\text { Broadleaved taxa, e.g. Ulmus sp., Juglans } \\
\text { sp., Salix sp., Aesculus sp., Alnus sp., Ilex } \\
\text { sp., Acer sp., Celtis sp., Mallotus sp., Fraxi- } \\
\text { nus sp., Skimmia sp. (mean } 3.45 \%) \text {. }\end{array}$ & $\begin{array}{l}\text { Broadleaved taxa, e.g. Juglans sp., } \\
\text { Betula sp., Rhododendron sp., Celtis } \\
\text { sp., Fraxinus sp. (mean 1.03\%), found } \\
\text { in all samples. }\end{array}$ & $\begin{array}{l}\text { sporadic. } \\
\text { Broadleaved taxa, e.g. Ulmus sp., Jug- } \\
\text { lans sp., Alnus sp., Celtis sp., Aesculus } \\
\text { sp., Fraxinus sp., Acer sp., Mallotus sp. }\end{array}$ \\
\hline $\begin{array}{l}\text { Syzygium sp., Mimosaceae (Mim } \\
\text { Shorea sp., Acacia sp. (tropical d }\end{array}$ & $\begin{array}{l}\text { Syzygium sp., sole representative of } \\
\text { tropical deciduous taxa (mean }<0.5 \%) \text {. }\end{array}$ & $S$ \\
\hline $\begin{array}{l}\text { taxa) (mean }<0 \\
\text { Shrubby taxa, } \\
\text { nea sp., Croton }\end{array}$ & $\begin{array}{l}\text { Ephedra sp., Dodonea sp., members } \\
\text { of Acanthaceae, Zizyphus sp., shrubby } \\
\text { taxa (mean 1\%), rare. }\end{array}$ & Croton sp., Dodonea \\
\hline $\begin{array}{l}\text { Poaceae (mean } 35.16 \% \text { ). } \\
\text { Cerealia (mean } 7.37 \% \text { ); other cultu } \\
\text { (Amaranthaceae, Caryophyllaceae, } \\
\text { sicaceae, Cannabis sativa, Artemis }\end{array}$ & $\begin{array}{l}\text { Poaceae (mean } 40.35 \%) \text {, Cerealia } \\
\text { (mean 6.71\%); other cultural taxa } \\
\text { (Amaranthaceae, Caryophyllaceae, also } \\
\text { Artemisia sp., Alternanthera sp. (mean } \\
10.98 \% \text { ). }\end{array}$ & $\begin{array}{l}\text { Poaceae (mean } 30.41 \\
3.40 \%) \text {; other cultura } \\
\text { thaceae, Caryophylla } \\
\text { also Cannabis sativa } \\
\text { (mean } 5.05 \%) \text {. }\end{array}$ \\
\hline $\begin{array}{l}\text { (mean } 12.88 \% \text { ). } \\
\text { Malvaceae, Asteroideae/Tubuliflo } \\
\text { rioideae/Liguliflorae (members of } \\
\text { ilies of Asteraceae), Aconitum sp. }\end{array}$ & $\begin{array}{l}\text { Other prominent terrestrial herbaceous } \\
\text { taxa, e.g. Asteroideae/Tubuliflorae } \\
\text { (members of sub-family of Asteraceae), } \\
\text { Malvaceae, Rosaceae, Xanthium sp. } \\
\text { (mean } 13.42 \%) \text {. }\end{array}$ & $\begin{array}{l}\text { Malvaceae, Asteroideae/Tubuliflorae } \\
\text { (members of sub-family of Asteraceae), } \\
\text { Aconitum sp., Oldenlandia sp., Vibur- } \\
\text { num sp., Xanthium sp., other terrestrial } \\
\text { herbaceous taxa, (mean 23.03\%). }\end{array}$ \\
\hline $\begin{array}{l}\text { (Oleaceae), Xant } \\
\text { terrestrial herba }\end{array}$ & $\begin{array}{l}\text { Marsh } \\
\text { aquati }\end{array}$ & ore- \\
\hline $\begin{array}{l}\text { Marshy/wetland ta } \\
\text { taxa (mean } 4.07 \% \text { ) }\end{array}$ & & $\begin{array}{l}<0.0 \\
\text { alga }\end{array}$ \\
\hline Algal & & \\
\hline & & \\
\hline $\begin{array}{l}0.50 \%) . \\
\text { Glomus sp. Diplodi } \\
\text { Tetraploa sp., Nigrc }\end{array}$ & $\begin{array}{l}\text { Nigrospora sp., Alternaria } \text { sp., Hel- } \\
\text { minthosporium sp. (mean } 15.32 \% \text { ). }\end{array}$ & $\begin{array}{l}\text { Glomus sp., Diplodia sp., Nigrospora sp., } \\
\text { Curvularia sp., Tetraploa sp., Cookeina } \\
\text { sp., Nigrospora sp., Alternaria sp., Hel- } \\
\text { minthosporium sp. (mean } 27.85 \%) \text {. }\end{array}$ \\
\hline
\end{tabular}

and subdominant taxa at the R.S. Pura site was explained, but principal components 1 and 2 could explain only $46 \%$ of it (Fig. 7).

\section{FROM OPEN AREAS OF BAJALTA VILLAGE, JAMMU DISTRICT}

The ten surface samples collected from open areas of Bajalta village, Jammu District (Fig. 2), showed higher frequency of conifers than of broadleaved among the arboreal pollen (AP) taxa. Non-arboreal pollen (NAP) taxa were less abundant in the total pollen rain (Fig. 5; Supplementary file 2 ). Table 2 presents detailed palynological results from this area. PCA explained $82 \%$ of the variance for the Bajalta site; principal components 1 and 2 explained about $60 \%$ of the total variance of the pollen taxa (Fig. 8).

\section{FROM OPEN AREAS OF SAMBA DISTRICT}

The ten surface samples collected from open areas of Samba District (Fig. 2) showed higher frequency of conifers than of broadleaved taxa among the arboreal pollen (AP) taxa. Nonarboreal pollen (NAP) taxa were abundant in the total pollen rain (Fig. 6; Supplementary file 2). Table 2 presents detailed palynological results from this area. PCA explained $86 \%$ of the total variance for the Samba site, with principal components 1 and 2 explaining $~ 65 \%$ of the total variance in the pollen percentages and distribution (Fig. 9).

\section{DISCUSSION}

\section{INFERENCES ON THE MODERN POLLEN RAIN-VEGETATION RELATIONSHIP}

Among the conifers, Pinus (saccate grain, regional taxon) showed high frequency in the pollen assemblages. This can be attributed to its high pollen productivity and pollen dispersal (Andersen, 1970; Bhattacharayya, 1989; Traverse, 2007; Pidek et al., 2010; Ertl et al. 2012; Kar et al., 2015, 2016; Quamar et al., 2018a, b; Bajpai and Kar, 2018; Quamar, 2020; 
Quamar and Kar, 2020 and references therein). The high sporopollenin content of the exine of Pinus pollen also helps make it resistant to oxidation and microbial attack (Havinga, 1967, 1984), allowing good preservation of it in the substrate. Pollen grains of Pinus have air bladders, and the taxon is anemophilous. The sacci increase the buoyancy of the pollen grains, favouring transport by wind, water (Suc and Drivaliari, 1991) and surface runoff (Frazer et al., 2020). The longer buoyancy time of the pollen grains (Pocknall, 1980) and their high fall speed $(0.031 \mathrm{~m} / \mathrm{s})$ (Xu et al., 2012) when their sacci become saturated with water allow them to be deposited differentially. Hopkins (1950) suggested that differential flotation, particularly between coniferous pollen and other taxa, could be due to weak differences in the density and surface/volume ratio of the grains (Flenley, 1971; Davis and Brubaker, 1973). The other coniferous temperate forest elements (extra-regional taxa), such as Cedrus sp., Abies sp., Picea sp., Larix sp., and Juniperus sp., have much lower values in the pollen spectra and are barely recorded. This behaviour of their pollen can be attributed to lower pollen productivity and pollen dispersal efficiency (Kar et al., 2015, 2016; Quamar et al., 2018a, b; Bajpai and Kar, 20018) and preservation potential (Quamar, 2020). The record of pollen of Cedrus sp., Abies sp.,and Picea sp. (saccate grains), as well as Larix sp. and Juniperus sp. (non-saccate grains, extra-regional taxa/temperate forest elements) from the study areas could reflect transport of their pollen through wind and/or water from the higher reaches of the Himalayas. Ulmus, Juglans and Mallotus are regional broadleaved taxa (Tab. 1) that were scarce in the pollen spectra, recorded at lower values. The other broadleaved taxa (extra-regional temperate elements), such as Alnus, Betula, Salix, Aesculus, Ilex, Acer, Celtis, Mallotus, Fraxinus, Rhododendron and Skimmia, were scattered in the pollen spectra at lower frequency than the conifers, especially Pinus, perhaps due to transport by wind and/or water from higher reaches of the Himalayas. Tropical deciduous forest elements (regional taxa), such as Syzygium, members of the subfamily Mimosoideae, Shorea and Acacia, appeared sporadically in the pollen spectra; this seems related to their entomophilous habit. The complete absence of other tropical deciduous forest elements (regional taxa), such as Terminalia, Emblica officinalis, Grewia, Mitragyna parvifolia, Mangifera indica, Madhuca indica, Lannea coromandelica, Bombax ceiba, Azadirachta indica, Melia azedarach, Eucalyptus, Ficus, Mallotus philippensis, Albizzia, Schleichera, Dalbergia sissoo, Morus alba, Butea monosperma, Tamarindus, Flacourtia, Cassia fistula, Sapindus and others from the pollen assemblages, could be ascribed to entomogamy and low pollen production (Cannel and Smith, 1984; Duan et al., 2009; Cariñanos et al., 2014; Quamar, 2020; Quamar and Bera, 2014a, b; Quamar and Kar, 2020; Quamar et al., 2018a, b and relevant references therein).

Ephedra sp., Dodonea sp., Croton sp., members of Acanthaceae, and Zizyphus sp. are prominent shrubby taxa that were sporadic in the pollen record. Ephedra, an anemophilous taxon, was sparse, perhaps due to its poor pollen dispersal and low preservation. The low pollen production or entomogamy could also be cited as reasons for the low representation of other shrubby taxa. Ephedra is an alpine scrub, whereas Dodonea and Croton are found in tropical, subtropical and warm-temperate areas of the Indian subcontinent. Ziziphus and members of the family Acanthaceae are common tropical deciduous forest elements (shrubby taxa) found around the study areas in the Jammu region. Poaceae and Amaranthaceae, being anemophilous taxa, form significant shares of the modern pollen assemblages of the study areas, followed by Cerealia. Caryophyllaceae, Brassicaceae, Artemisia, Alternanthera, Cannabis sativa, Plantago and members of Urticaceae have meagre shares in the modern pollen assemblages. The pollen record of Cerealia and other cultural plant taxa, such as Amaranthaceae, Brassicaceae, Caryophyllaceae, Artemisia sp., Alternanthera sp., Cannabis sativa, Plantago and members of Urticaceae, is indicative of agricultural practice, as well as other human activities in and around the study areas. Asteroideae/Tubuliflorae (a subfamily of Asteraceae) showed high values, which could indicate pastoral activity around these areas of the Jammu region (Mazier et al., 2006). Caryophyllaceae and Artemisia also point to grazing of open landscape types around the study areas (Van Joolen, 2003). Members of Malvaceae have overall good representation in the pollen spectra, which could indicate fair pollen preservation, despite entomogamy. Cichorioideae/Liguliflorae, Aconitum (Ranunculaceae), Oldenlandia, Viburnum, Helicteris, Jasminum (Oleaceae), Rosaceae and 


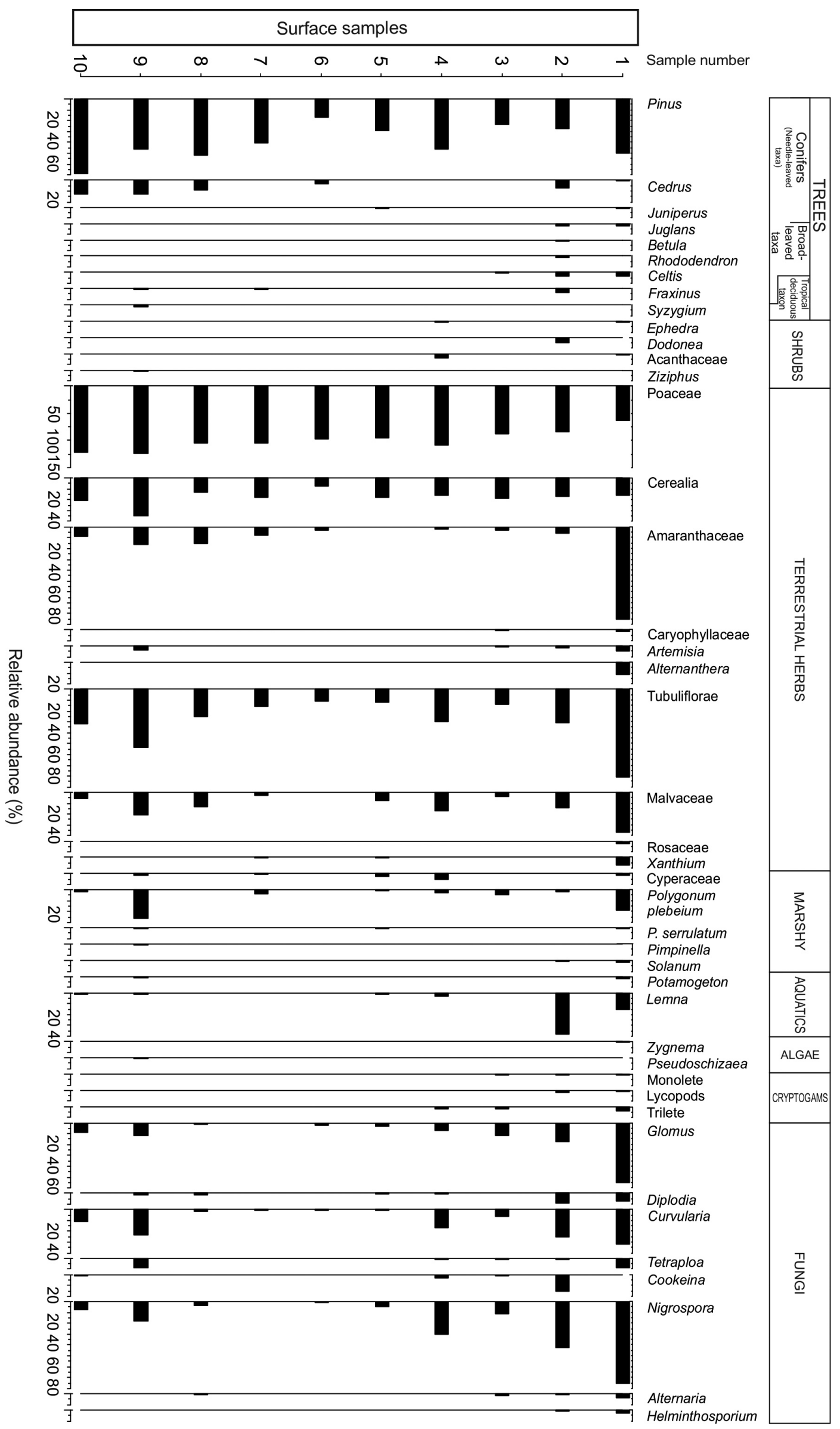

Fig. 5. Modern pollen spectra of from open areas of Bajalta village, Jammu District, Jammu and Kashmir, India 


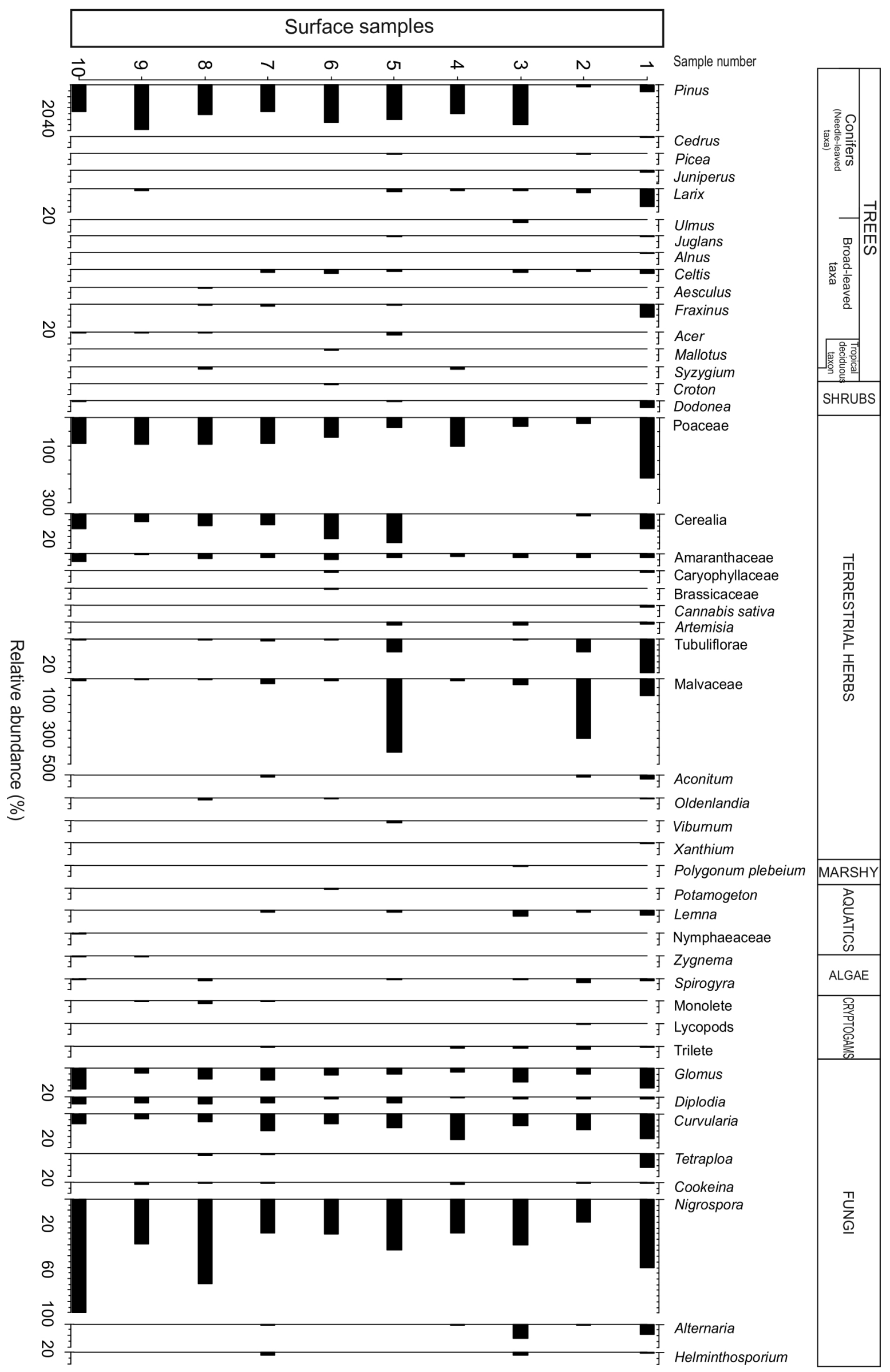

Fig. 6. Modern pollen spectra from open areas of Samba District, Jammu region, Jammu and Kashmir, India 
Xanthium were sporadically recovered; this could be due to entomogamy of these terrestrial herbaceous taxa (Vincens et al., 1997; Quamar et al., 2018a, b; Quamar, 2020; Quamar and Kar, 2020). Low dispersal efficiency, as well as poor preservation of their pollen in the studied substrate could also be cited as reasons for the irregularity of their representation in the assemblages. Nor can we rule out oxidation and high $\mathrm{pH}$ of the studied natural pollen trapping media/substrates, coupled with microbial degradation of the pollen (Quamar and Bera, 2014a, b, 2017; Quamar and Kar, 2020 and references cited therein). The record of marshy (wetland) taxa, such as Cyperaceae, Polygonum plebeium, Polygonum serrulatum, Chrozophora, Pimpinella, and Solanum, indicates wet conditions around the sampling sites. We also found aquatic taxa, such as Potamogeton sp., Lemna sp., Typha sp., members of the family Nymphaeaceae and Utricularia sp., as well as algal spores, including zygospores of Zygnema and Spirogyra, and Pseudoschizaea; they may have originated from waterbodies and/or aquatic environments around the sampling areas (Pišút et al., 2010). Monolete and trilete fern spores and lycopods could indicate high water availability and the presence of mesic habitats (Kato, 1993). The high percentages of Glomus may indicate local soil erosion (Medeanic and Silva, 2010). The presence of Glomus, Diplodia, Curvularia, Tetraploa, Nigrospora, Cookeina, Alternaria and Helminthosporium reflects warm and humid climate around the study areas (Quamar, 2015).

In the present study, principal component analysis (PCA) was used for the unconstrained ordination axes, corresponding to the directions of the greatest variability within the data set. Canoco 5 allows the ordination method to indicate the variance through $\mathrm{PC} 1$ and $\mathrm{PC} 2$, and in this study the pollen relation was determined using PCA. The total variance explained by PCA was $68 \%$, while PC1 and PC2 explained 46\%. In PCA of the data from the R.S. Pura site, most of the variance (60-70\%) was attributed to Typha, Ulmus, Tetraploa and Curvularia. The lower variance for this site is accounted for by Shorea, Oldenlandia, Cyperaceae, Monolete, Zygnema and a few others (variance only 30-40\%). For Poaceae, Amaranthaceae, Alternaria, Lemna, trilete spores, Polygonum plebeium, Glomus and many others the variance ranged from $-60 \%$ to $-10 \%$ (Fig. 7 ). The mixed nature of variance for the taxa suggests that the data for this site are related to its environmental setting.

At the Bajalta site, the total variance explained by PCA was $82 \%$; PC1 and PC2 could explain $60 \%$ of the variation in the pollen assemblage. The distance between the symbols in the pollen composition approximates dissimilarity as measured by their Euclidean distance. For the Bajalta site, principal components 1 and 2 showed $60-70 \%$ variance for Cookenia, Rhododendron, Lemna, Lycopods, Dodonea, Nigrospora and a few others, indicating dominance of indigenous taxa around the depositional site. Solanum, Malvaceae, Glomus, Helminthosporium, Artemisia, Rosaceae and a few others gave negative variance of $-50 \%$ to $-70 \%$, indicating dominance of local vegetation, mainly herbs and lower plants rather than tree taxa (Fig. 8). Thus, PCA suggests that the depositional site was controlled by local environmental conditions rather than long-distance transport.

For the Samba site, $86 \%$ of the total variance of the pollen assemblage was explained. PC1 and PC2 explained 65\% percent of it. Principal components 1 and 2 showed that Ulmus, Polygonum plebeium, Lemna, Artemisia, trilete spores and Alternaria accounted for $70-85 \%$ of the variance, suggesting altitudinal control of the taxa, with moist conditions. Pinus, Glomus, Curvularia, Poaceae and Nigrospora accounted for $50-70 \%$ of the variance, reflecting cool and dry conditions and local erosion around the depositional setting. Monolete, Diplodia, Zygnema, Nymphaea, Acer, and many others showed -30 to $-50 \%$ variance, reflecting humid conditions around the sampling area. Picea, Juglans, Alnus, Juniperus, Viburnum, lycopods and a few others indicate altitudinal variance in PCA for this site (Fig. 9). Generally, the data for the depositional site clearly indicates an altitudinal regime with moist conditions.

\section{AGRICULTURAL PRACTICE AROUND THE STUDY AREA}

Agricultural practice around the study areas is suggested by the records of pollen of Cerealia ( $>40 \mu \mathrm{m}$ diameter) and other cultural plant taxa. Between-site differences in the counts of Cerealia pollen and other cultural plant taxa reflect corresponding differences in the intensity of agricultural practice and other human activities around the study areas. 


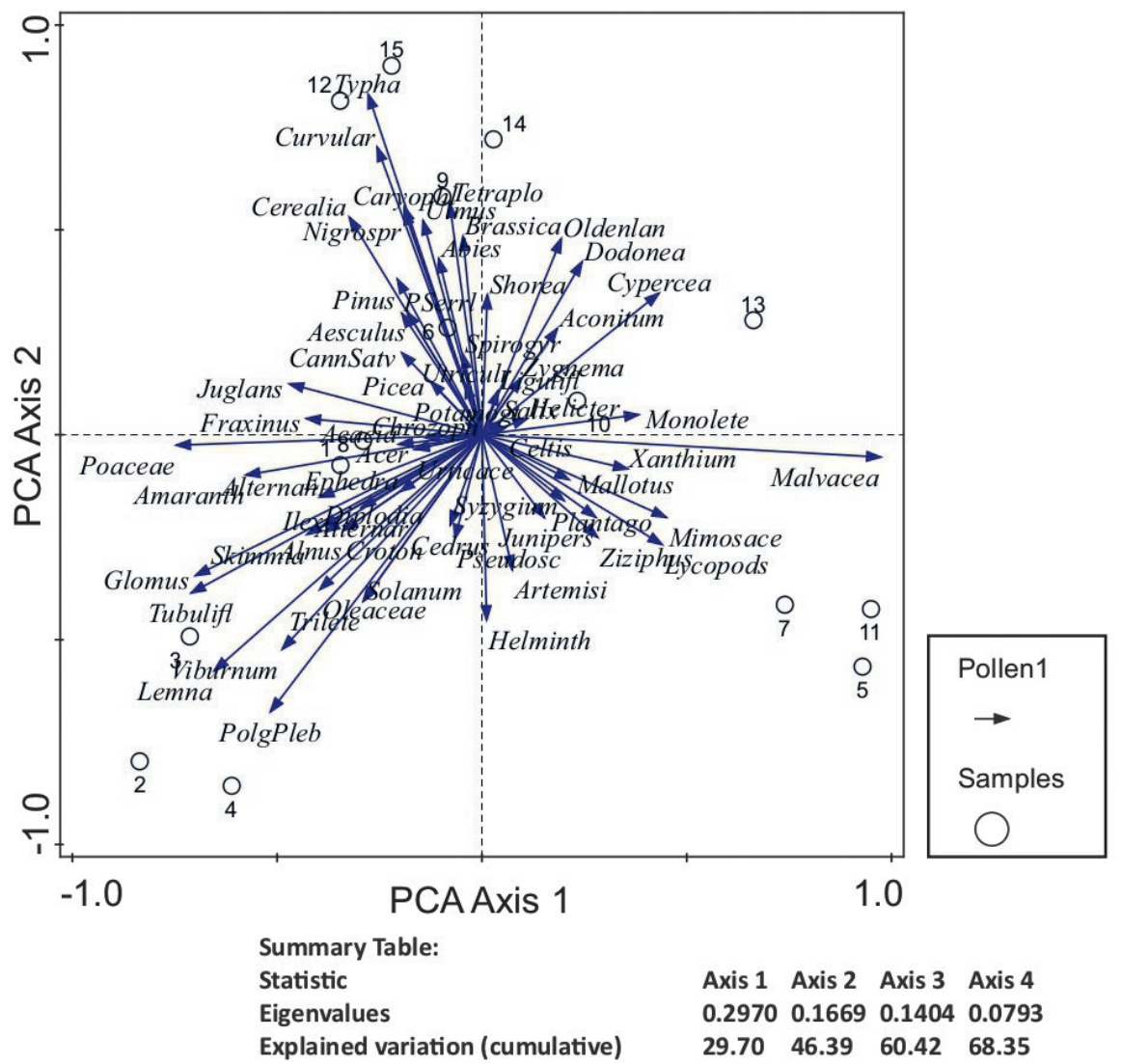

Fig. 7. Results of PCA analysis of surface soil samples in relation to the pollen assemblages and extant vegetation of R.S. Pura, Jammu District, Jammu region

In addition to Cerealia we also recorded Amaranthaceae, Caryophyllaceae, Brassicaceae, Cannabis sativa, Artemisia, Alternanthera, Plantago and Urticaceae around the R.S. Pura Sector of Jammu District; Amaranthaceae, Caryophyllaceae, Artemisia, and Alternanthera were recovered around the Bajalta area of Jammu District; around the Samba District of the Jammu region we recorded Amaranthaceae, Caryophyllaceae, Brassicaceae, Cannabis sativa and Artemisia.

The record of Poaceae pollen could be related to opening of the forest (perhaps reflecting human activity; Moss et al., 2005). When found in high numbers, it suggests an undisturbed depositional environment around the study areas (Brown, 1985; Catto, 1985; Fall, 1987; Bush, 2000; Behling and Negrelle, 2001).

\section{COMPARISON WITH RESULTS FROM OTHER STUDIES OF THE JAMMU REGION}

\section{Akhnoor (Jammu District)}

Inferences about the modern pollen and vegetation from a study done in Akhnoor, Jammu District (Quamar, 2020), where the samples (moss polsters) were collected from the edge of forested areas, agree with our finding of high representation of Pinus and lower values of other coniferous (extra-regional) taxa. Broadleaved regional subtropical and/or extra-regional (temperate) taxa were sporadic and found at very low frequency; they may have been transported by wind and/or water from upland areas or the higher reaches of the Himalayas. Among the broadleaved subtropical (regional) taxa, Mallotus was well represented in the pollen assemblages of the Akhnoor samples (but had lower values in the samples from R.S. Pura, Jammu District, and Samba District, and was absent from the samples from Bajalta village, Jammu District), perhaps due to their local presence and high pollen dispersal and preservation. Carpinus, a temperate (extra-regional) broadleaved taxon, was also over-represented in the pollen spectra of Akhnoor (but was absent from the samples from R.S. Pura, Bajalta village, Jammu District, and Samba District), perhaps due to transport by wind and/or water from nearby higher reaches of the Himalayas, as well as good preservation of their pollen in the studied substrate from Akhnoor. Subtropical deciduous forest elements were either sporadic 


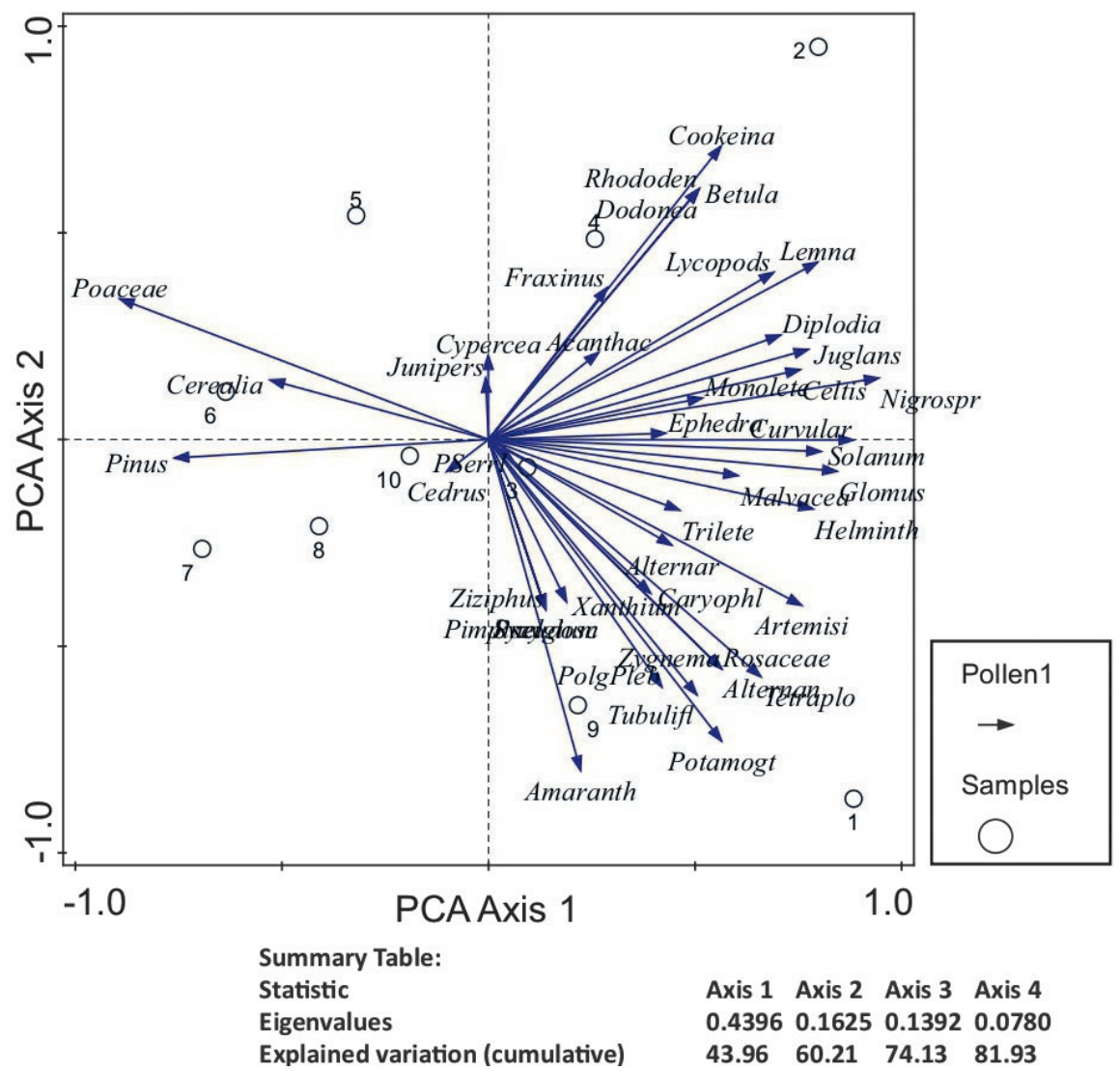

Fig. 8. Results of PCA analysis of surface soil samples in relation to the pollen assemblages and extant vegetation of the Bajalta area of Jammu District, Jammu region

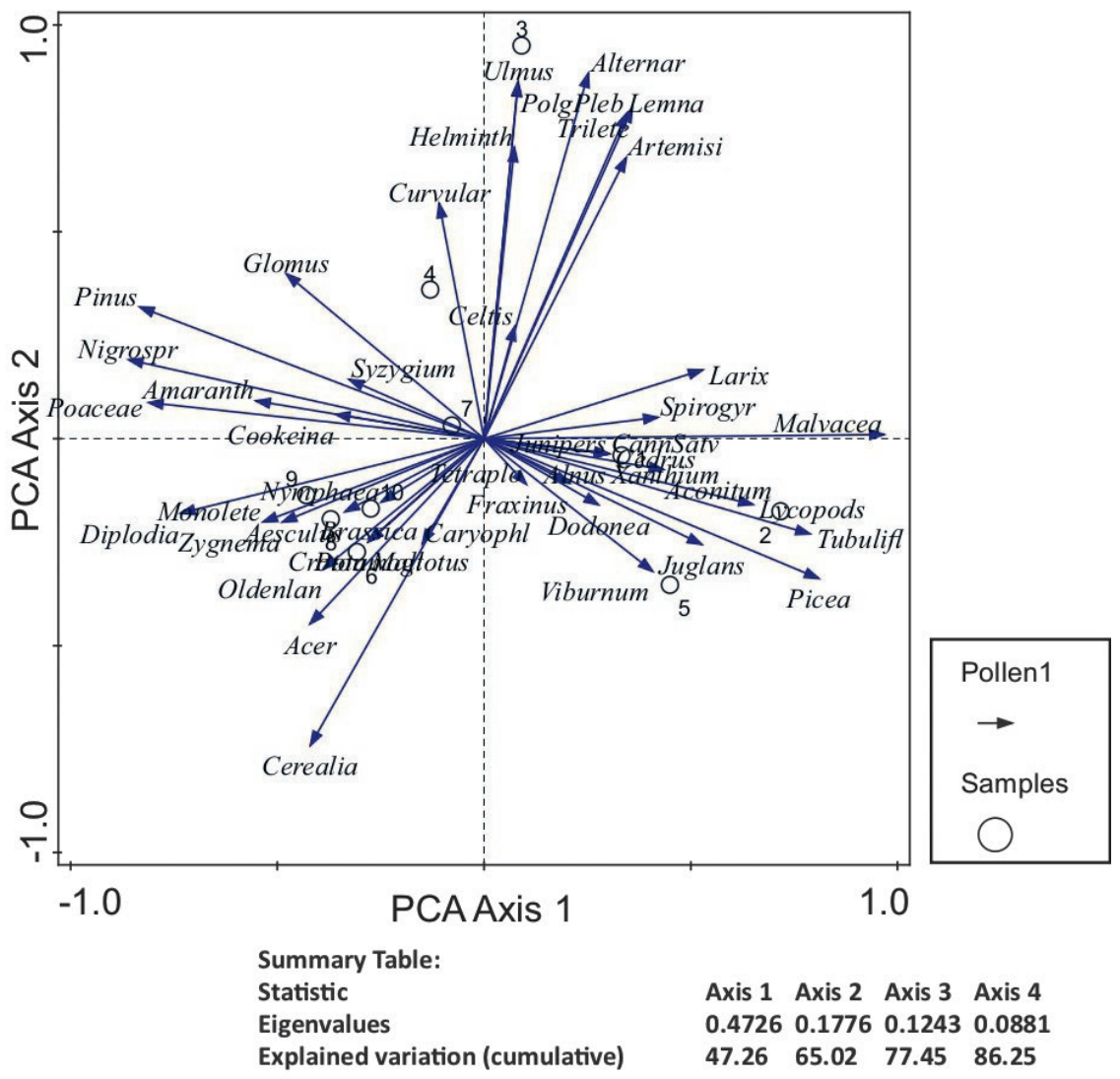

Fig. 9. Results of PCA analysis of surface soil samples in relation to the pollen assemblages and extant vegetation of Samba District, Jammu region 
or palynologically silent (present in the extant vegetation but absent in the recovered pollen assemblages) in the samples from open areas of R.S. Pura, Bajalta village (Jammu District) and Samba District, as well as from Akhnoor. This discrepancy in their representation in the pollen spectra from these areas can be explained by the fact that they are not wind-pollinated (rather entomogamy) and also not high pollen producers. The palynological results for the shrubby taxa were similar in all the studied areas. Among the herbaceous taxa, Poaceae showed lower values in the Akhnoor samples than in the present study. The values of Cerealia and other cultural plant taxa as well as other terrestrial herbaceous taxa, marshy/wetland taxa, aquatic taxa, algal remains, pteridophytic taxa, and fungal spores were more or less similar between Akhnoor and the present study. Similar inferences were drawn from these areas.

\section{Udhampur}

A study of the modern pollen rain-vegetation relationship in Udhampur District (Quamar et al., 2018a), where the samples (moss cushions) were collected from open areas of the forest, showed high frequency of Pinus, as in the present study. Among the conifers, Tsuga (extra-regional temperate taxon) was recorded in Udhampur but not in the present study, showing comparatively low values in the pollen spectra; its pollen productivity is lower than Pinus, and its pollen dispersal and preservation is low. Quercus is a regional broadleaved taxon recorded from Udhampur but not in the present study. Other broadleaved (extraregional temperate) taxa, such as Carpinus Corylus and Elaeocarpus, were recorded sporadically and at low frequency in Udhampur but not in the present study. Their pollen productivity is low as compared to Pinus sp. This distribution could be explained by their lower pollen productivity than Pinus, poor pollen dispersal and poor pollen preservation in the substrate, and transport by wind and/or water from nearby higher reaches of the Himalayas. Skimmia and Indigofera are shrubby taxa recorded sporadically from Udhampur but not in the present study, perhaps due to poor pollen dispersal and poor preservation, low pollen production or entomogamy. Among the herbs, Poaceae, Cerealia and other cultural plant taxa, as well as other terrestrial herbaceous taxa, marshy/wetland taxa, aquatic taxa, algal remains, pteridophytic taxa and fungal spores, reached more or less the same values in Udhampur and the present study.

\section{Reasi}

In a study of the dispersal of modern pollen in Reasi District (Quamar et al., 2018b), where samples (moss polsters) were collected from open areas of the forest along the ReasiKatra Route, Pinus occurred at high frequency and dominated the pollen rain around the study area; the same was true in the present study. The conifers Podocarpus and Tsuga (extraregional temperate taxa) were recorded in Reasi at low values but were not encountered in the present study. Quercus (regional broadleaved taxon) as well as Carpinus, Corylus, and Elaeocarpus (extra-regional temperate broadleaved taxa) were recorded at various low frequencies in Reasi but not in the present study; these taxa show low pollen productivity, poor pollen dispersal, and poor preservation in the pollen-trapping media/substrates used. Besides low pollen productivity, low pollen dispersal and poor preservation of the pollen of extra-regional temperate conifers, as well as broadleaved taxa, their transport by wind and/or water from nearby upland areas cannot be ruled out and may be the main reason for their lower values in, or absence from, the pollen assemblages of Reasi and the present study, due to their entomophily. The pollen values for Poaceae, Cerealia and other cultural plant taxa, such as members of Amaranthaceae, Caryophyllaceae, Brassicaceae, Artemisia and Cannabis sativa, as well as Asteroideae/Tubuliflorae, Cichorioideae/Liguliflorae (Asteraceae), Malvaceae, Xanthium, Justicia, Oldenlandia, Aconitum, Valeriana and Rosaceae (cf. Potentilla), prominent terrestrial herbaceous taxa, were more or less the same for Reasi and the present study. Marshy/wetland taxa, aquatic taxa, algal remains, pteridophytic taxa, and fungal spores trended almost the same for Reasi and for the present study.

Summing up, it can be stated that (1) Pinus (regional conifers) dominated the pollen assemblages of both study areas; (2) other conifers (regional and/or extra-regional taxa) showed lower values than Pinus did; (3) subtropical deciduous (regional) taxa were sporadic or palynologically silent; (4) broadleaved and shrubby regional and/or extra-regional taxa also showed lower values or were palynologically silent; (5) Poaceae (grasses), Cerealia and 


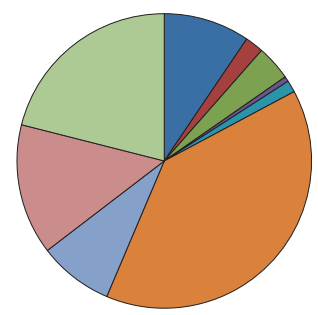

RS Pura (Jammu District)

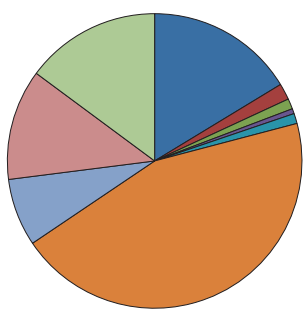

Bajalta Village (Jammu District)

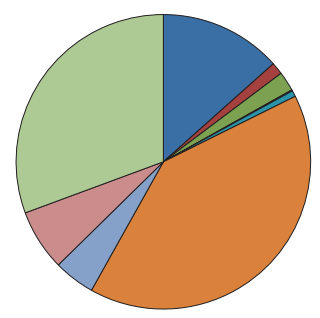

Samba District

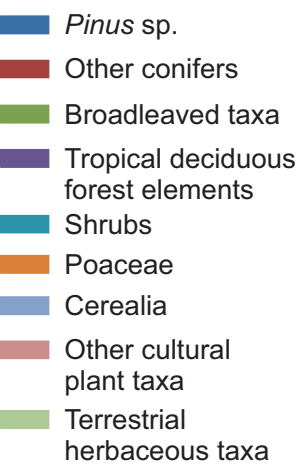

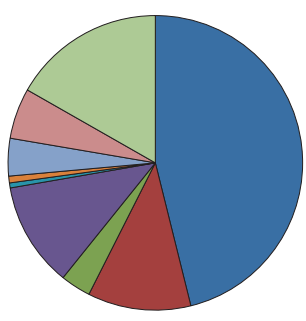

Akhnoor (Jammu District)

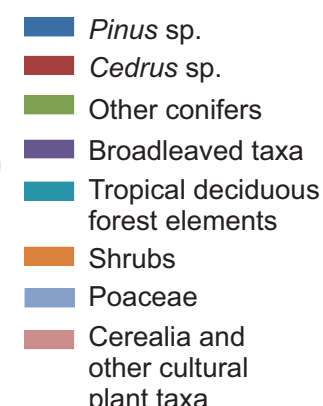
plant taxa

Terrestrial herbaceous taxa
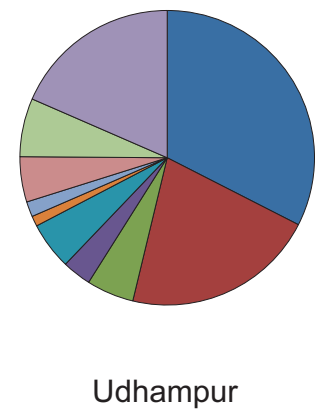

District

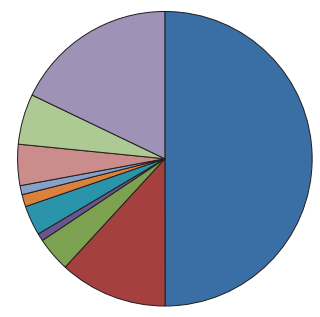

Reasi

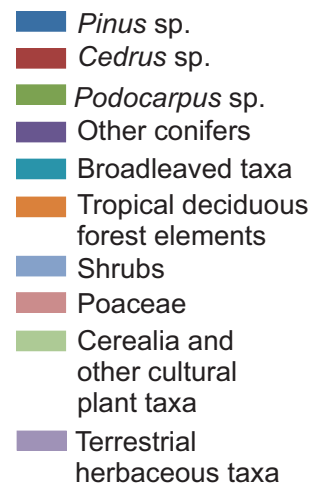

Fig. 10. Pie charts in the first row show the relative abundance of the chief contributors to the forest constituents in the modern pollen assemblages around the study areas. Pie charts in the second row show the relative abundance of the chief contributors to the forest elements in the modern pollen rain from Akhnoor (Jammu District), as well as from Udhampur District and Reasi District

other cultural plant taxa had more or less similar shares in the pollen assemblages from all studied areas; (6) other terrestrial taxa were rare and less abundant, except for Asteroideae/ Tubuliflorae and to some extent Malvaceae; and (7) wetland (marshy) and aquatic taxa, algal, pteridophytic and fungal spores showed similar lower values in the pollen assemblages of all studied areas.

Pie charts (Fig. 10) show the chief contributors to the forest elements of the modern pollen assemblages of R.S. Pura and Bajalta village in Jammu District, and Samba District in the Jammu region (in the first row). They are also compared with the modern pollen assemblages from Akhnoor in Jammu District, as well as Udhampur District and Reasi District (in the second row).

The extended R-value model approach (Parsons and Prentice, 1981; Prentice and Parsons, 1983; Sugita, 1993, 1994) should be applied to achieve the best approximation of a "pollen sample's view" of the landscape (Prentice and Webb, 1986; Sugita, 1994; Calcote, 1995). The modelling approach corrects the non-linearities (Fagerland effect: Fagerland, 1952) that arise from the use of pollen percentage data. Also, the relevant pollen source area and the distance-weighted plant abundance can be defined, which helps improve the pollen representation (pollen production and dispersal) as well as transport and preservation, and ultimately this can better clarify the modern pollen rain-vegetation relationship of an area.

\section{FACTORS AFFECTING THE MODERN POLLEN-VEGETATION RELATIONSHIP}

Insights gained from establishing the relationship between modern pollen assemblages and extant vegetation can help in reconstructing past vegetation and the associated palaeoclimate. In this study we generated a comparative data set in order to estimate the extent to which various plant taxa/groups of the present-day vegetation are represented in modern pollen assemblages. The relationship between modern pollen assemblages and extant vegetation is affected by various factors, including pollen productivity and dispersal mechanisms (Ma et al., 2008).

Besides the variation in the pollen productivity, dispersal, transport and preservation 
potential of an individual taxon, which causes a non-linear relationship (Fagerland effect: Fagerland, 1952), climatic factors (e.g. temperature, precipitation/rainfall, relative humidity, air pressure, wind speed, wind direction, human disturbances affecting the source vegetation: Sugita, 2007a, b), a long-term sampling strategy (to control for differences in flowering periodicity), differences in pollen transport distance, soil $\mathrm{pH}$, and the characteristics of the natural pollen-trapping media/substrates (soil surface samples, moss cushions, surface sediment from lakes, especially larger lakes) can affect the pollen rain-vegetation relationship observed in an area. Moss polsters, in fact, best reproduce the overall extant vegetation scenario in any area (Quamar and Bera, 2017) by providing an acidic and (often) waterlogged substrate conducive for good preservation of pollen grains and spores, ultimately representing the local contemporary vegetation faithfully (Wilmshurst and McGlone, 2005). Moss polsters also reflect pollen deposition over periods ranging from a year to fifteen years (Crowder and Cuddy, 1973; Caseldine, 1981; Bradshaw, 1981; Cundill, 1991). Surface soils collect pollen for a few to many years, depending on the sedimentation rate, but the exact period a soil sample covers is difficult to determine. In addition, due to mechanical and chemical corrosion, fragile grains with thin exine may be destroyed in soils (Wilmshurst and McGlone, 2005); that is why many plants are always under-represented or less represented in soil samples. Surface sediments from the central part of larger lakes have a larger pollen source area; their pollen assemblages contain more regional pollen and also are not distorted by the local pollen, consequently enabling better interpretation of regional vegetation (Qin et al., 2015).

\section{CONCLUSIONS}

1. The pollen assemblages showed overrepresentation of Pinus.

2. The over-representation of Pinus, as well as under-representation and/or absence of other coniferous, broadleaved (regional and/or extra-regional) taxa, together with the record of transported/extra-regional taxa in the pollen assemblages, distorts the real picture of extant vegetation. Ultimately the pollen assemblages do not fully correspond to the extant vegetation.
3. Subtropical deciduous (regional) and shrubby taxa (regional and/or extra-regional) taxa were also under-represented in the pollen assemblages, presenting a false picture of the extant vegetation.

4. Pollen of the terrestrial herbaceous taxa Poaceae, Cerealia, Asteroideae/Tubuliflorae, and Malvaceae, though showing high values, represented only part of the extant ground vegetation.

5. PCA showed that different environmental, altitudinal and local climatic factors control the pollen assemblage, as supported by the significant variance of PCA 1 and 2 .

The present study should facilitate the confident use of fossil pollen data for reconstruction of vegetation dynamics and the associated climate in the study area and in similar areas on the Indian subcontinent.

\section{ACKNOWLEDGEMENTS}

We thank Dr. (Mrs.) Vandana Prasad, Director of the Birbal Sahni Institute of Palaeosciences (BSIP), Lucknow (Uttar Pradesh), India, for providing the infrastructure facilities needed to complete the research work and also for permission to publish. We also thank the two anonymous reviewers for providing their critical comments and detailed authoritative suggestions twice, which have substantially improved the paper. Thanks are also due to Dr. Maria Barbacka, Editor, Acta Palaeobotanica, for her kind guidance, encouragement and co-operation. Md. Firoze Quamar is grateful to the Department of Science \& Technology (DST), Ministry of Science \& Technology, Government of India, New Delhi, India, for funding to conduct the study (DST Fast Track Young Scientist Project; SR/ FTP/ES-81/2013, dated 20/01/2014).

\section{REFERENCES}

Andersen, S.T., 1970. The relative pollen productivity and pollen representation of North European trees, and correction factors for tree pollen spectra: determined by surface pollen analyses from forests. Geological Survey of Denmark II Series 96, 1-99.

Bajpai, R., Kar, R., 2018. Modern pollen deposition in glacial settings in the Himalaya (India): abundance of Pinus pollen and its significance. Palynology 42(4), 475-482. https://doi.org/10.1080/01916122.2 017.1407835

Behling, H., Negrelle, R.R.B., 2001. Tropical rain forest ad cliamate dynamics of the Atlantic lowland, southern Brazil, during the Late Quaternary. Quaternary Research 56, 383-389. https://doi. org/10.1006/qres.2001.2264

Bhattacharya, A., 1989. Modern pollen spectra from Rohtang range, Himachal Pradesh. Journal of Palynology 25, 121-131. 
Birks, H.J.B., Berglund, B.E., 2018. One hundred years of Quaternary pollen analysis 1916-2016. Vegetation History and Archaeobotany (B), 1-39. https://doi.org/10.1007/s00334-017-0630-2

Bradshaw, R.H.W., 1981. Modern pollen representation factors for woods in South-East England. Journal of Ecology 69, 45-70. https://doi.org/10.2307/2259815

Broothaerts, N., Robles-López, S., Abel-Schaad, D., Pérez-Díaz, S., Alba-Sánchez, F., Luelmo-Lautenschlaeger, R., Glais, A., López-Sáez, J.A., 2018. Reconstructing past arboreal cover based on modern and fossil pollen data: a statistical approach for the Gredos Range (Central Spain). Review of Palaeobotany and Palynology 255, 1-13. https:// doi.org/10.1016/j.revpalbo.2018.04.007

Brown, A.G., 1985. The potential use of pollen in the identification of suspended sediment sources. Earth Surface Processes and Landforms 10, 27-32. https://doi.org/10.1002/esp.3290100106

Bush, M., 2000. Deriving response matrices from Central American modern pollen rain. Quaternary Research 54, 132-143. https://doi.org/10.1006/qres.2000.2138

Calcote, R., 1998. Identifying forest stand types using pollen from forest hollows. The Holocene 84, 423432. https://doi.org/10.1191/095968398670894847

Calcote, R., 1995. Pollen source area and pollen productivity: evidence from forest hollows. Journal of Ecology 83, 591-602. https://doi.org/10.2307/2261627

Cannell, M.G.R., Smith, R.I., 1984. Spring frost damage on young Picea sitchensis 2. Predicted dates of budburst and probability of frost damage. Forestry 57(2), 177-197. https://doi.org/10.1093/forestry/57.2.177

Cariñanos, P., Alcázar, P., Galán, C., Domínguez, E., 2014. Environmental behaviour of airborne Amaranthaceae pollen in the southern part of the Iberian Peninsula, and its role in future climate scenarios. Science of the Total Environment 470-471, 480-487. https://doi.org/10.1016/j.scitotenv.2013.10.024

Caseldine, C., 1981. Surface pollen studies across Bankhead moss, Fife, Scotland. Journal of Biogeography 8, 7-25. https://doi.org/10.2307/2844589

Catto, N.R., 1985. Hydrodynamic distribution of palynomorphs in a fluvial succession, Yukon. Canadian Journal of Earth Sciences 22, 1552-1556. https://doi.org/10.1139/e85-163

Champion, H.G., Seth, S.K., 1968. A Revised Survey of Forest Types of India, Government of India Press, New Delhi.

Chakrapani, G.J., 2005. Factors controlling variations in river sediment loads. Current Science 88(4), 569-575.

Chen, X., Huang, X., Wu, D., Zhang, X., Dodson, J., Zhou, A., Chen, F., 2017. Modern pollen assemblages in topsoil and surface sediments of the Xingyun Lake catchment, central Yunnan Plateau, China, and their implications for interpretation of the fossil pollen record. Review of Palaeobotany and Palynology 214, 1-12. https://doi.org/10.1016/j. revpalbo.2017.01.003
Crowder, A.A., Cuddy, D.G., 1973. Pollen in a small river basin: Wilton Creek, Ontario. In: Birks, H.J.B., West, R.G. (eds), Quaternary Plant Ecology. Blackwell, Oxford, pp. 61-78.

Cundill, P.R., 1991. Comparison of moss polsters and pollen trap data: a pilot study. Grana 30, 301-308. https://doi.org/10.1080/00173139109431984

Davis, M.B., Brubaker, L.B., 1973. Differential sedimentation of pollen grains in lakes. Limnology and Oceanography 18(4), 635-646. https://doi. org/10.4319/lo.1973.18.4.0635

Duan, Y.W., Zhang, T.F., He, Y.P., Liu, J.Q., 2009. Insect and wind pollination of an alpine biennial Aconitum gymnandrum (Ranunculaceae). Plant Biology 11, 796-802. https://doi.org/10.1111/j.14388677.2009.00195.x

Erdtman, G., 1943. An Introduction to Pollen Analysis. Chronica Botanica Company, Waltham, Mass. USA.

Ertl, C., Pessi, A.M., Huusko, A., Hicks, S., Kubin, E., Heino, S., 2012. Assessing the proportion of "extra local" pollen by means of modern aerobiological and phonological records- an example from Scots pine (Pinus sylvestris L.) in northern Finland. Review of Palaeobotany and Palynology 185, 1-12. https:// doi.org/10.1016/j.revpalbo.2012.07.014

Faegri, K., Iversen, J., 1964. Textbook of Pollen Analysis. John Wiley \& Sons, Denmark.

Faegri, K., Iversen, J., 1989. Textbook of Pollen Analysis. Wiley, Chichester, New York.

Fagerland, F., 1952. The real significance of pollen diagrams. Botaniska Notiser 105, 185-224.

Fall, P.L., 1987. Pollen taphonomy in a canyon stream. Quaternay Research 28, 393-406.

Flenley, J.R., 1971. Measurements of the specific gravity of the pollen exine. Pollen Spores 13, 179-186.

Frazer, H., Prieto, A.R., Carbonella, J.C., 2020. Modern pollen source and spatial distribution from surface lake sediments in the southwestern Pampa grasslands, Argentina: Implications to interpret Holocene pollen records. Review of Palaeobotany and Palynology 277, 104207. https://doi.org/10.1016/j. revpalbo.2020.104207

Gaceur, E., Desprat, S., Rouis-Zargouni, I., Hanquiez, V., Lebreton, V., Combourieu Nebout, N., Kallel, N., 2017. Pollen distribution in surface sediments of the northern Lower Medjerda valley (northeastern Tunisia). Review of Palaeobotany and Palynology 247, 13-25. https://doi. org/10.1016/j.revpalbo.2017.07.009

Ganjoo, R.K., Kumar, V., 2012. Late Quaternary fine silt deposits of Jammu, NW Himalaya: Genesis and climatic significance. Journal of Earth System Sciences 121(1), 165-182. https://doi.org/10.1007/ s12040-011-0134-x

Grimm, E.C., 1990. TILIA and TILIA.GRAPH, PC spreadsheet and graphics software for pollen data. INQUAWorking Group on Data-handling Methods Newsletter 4, 5-7. 
Gupta, H.P., Sharma, C., 1987. Pollen Flora of NorthWest Himalaya. Indian Association of Palynostratigraphers. Lucknow, India. $181 \mathrm{p}$.

Harris, I., Jones, P.D., Osborn, T.J., Lister, D.H., 2014. Updated high-resolution grids of monthly climatic observations-the CRU TS 3.10. International Journal of Climatology 34, 623-642. https:// doi.org/10.1002/joc.3711

Havinga, A.J., 1967. Palynology and pollen preservation. Review of Palaeobotany and Palynology 2, 81-98. https://doi.org/10.1016/0034-6667(67)90138-8

Havinga, A.J., 1984. A 20-year experimental investigation into the differential corrosion susceptibility of pollen and spores in various soil types. Pollen Spores 26, 541-558.

Hopkins, J.S., 1950. Differential flotation and deposition of coniferous and deciduous tree pollen. Ecology 31(4), 633-641. https://doi.org/10.2307/1931580

Jolliffe, I.T., Cadima, J., 2016. Principal component analysis: a review and recent developments. Philosophical Transactions of the Royal Society A 374, 20150202. https://doi.org/10.1098/rsta.2015.0202

Kar, R., Bajpai, R., Singh, A.D., 2015. Modern pollen assemblages from Hamtah and Chhatru glaciers, Lahaul-Spiti, India: Implications for pollen-vegetation relationship in an alpine arid region of western Himalaya. Quaternary International 371, 102-110. https://doi.org/10.1016/j.quaint.2015.02.047

Kar, R., Bajpai, R., Mishra, K., 2016. Modern pollenrain in Kedarnath: implications for past vegetation and climate. Current Science 110(3), 296-298.

Kato, M., 1993. Biogeography of ferns: dispersal and vicariance. Journal of Biogeography 20, 265-274. https://doi.org/10.2307/2845634

Köppen, W., 1936. Das geographische System der Klimate. In: Köppen, W., Geiger, R. (eds) Handbuch der Klimatologie. Gebrüder Borntraeger, Berlin, p. 1-44.

Ma, Y., Liu, K., Feng, Z., Sang, Y., Wang, W., Sun, A., 2008. A survey of modern pollen and vegetation along a south-North transect in Mongolia. Journal of Biogeography 35, 1512-1532. https://doi. org/10.1111/j.1365-2699.2007.01871.x

Mazier, F., Gallop, D., Brun, C., Buttler, A., 2006. Modern pollen assemblage from grazed vegetation in western Pyrenees, France: a numerical tool for more precise reconstruction of past cultural landscapes. The Holocene 16, 91-103. https://doi. org/10.1191/0959683606hl908rp

Medeanic, S., Silva, M.B., 2010. Indicative value of non-pollen palynomorphs (NPPs) and palynofacies for palaeoreconstructions: Holocene Peat, Brazil. International Journal of Coal Geology 84, 248-257. https://doi.org/10.1016/j.coal.2010.08.015

Mir, A.M., 2003. Geography of Jammu: A Regional Analysis. New Delhi: Dilpreet Publishing House.

Moore, P.D., Webb, J.A., 1978. An illustrated guide to pollen analysis. London: Hodder \& Stoughton.

Moss, P.T., Peter Kershaw, A., Grindrod, J., 2005. Pollen transport and deposition in riverine and marine environments within the humid tropics of northeastern Australia. Review of Palaeobotany and Palynology 134, 55-69. https://doi.org/10.1016/j.revpalbo.2004.11.003

Nair, P.K.K., 1965. Pollen Grains of Western Himalayan Plants. Asia Publishing House, Bombay, India.

Nayar, T.S., 1990. Pollen Flora of Maharashtra State, India. Today and Tommarrow's Printers \& Publishers, New Delhi.

Pandita, D., Pandita, A., Pandita, S., 2014. The revitalizing and recuperative higher Tracheophytes of Jammu province, Jammu and Kashmir (India). International Journal of Indigenous Medicinal Plants 47(1), 1603-1620.

Parsons, R.W., Prentice, I.C., 1981. Statistical approaches to $R$-values and pollen vegetation relationship. Review of Palaeobotany and Palynology 32, 127-152. https://doi.org/10.1016/0034-6667(81)90001-4

Pidek, I.A., Piotrowska, K., Kasprzyk, I., 2010. Pollenvegetation relationships for pine and spruce in southeast Poland on the basis of volumetric and Tauber trap records. Grana 49, 215-226. https:// doi.org/10.1080/00173134.2010.514006

Pišút, P., Bř́ízová, E., Čejka, T., Pipík, R., 2010. Paleofloristic and paleofaunistic analysis of Dudváh River oxbow and implication for Late Holocene paleoenvironmental development of the Žitný ostrov Island (SW Slovakia). Geologica Carpathica, 61(6), 513533. https://doi.org/10.2478/v10096-010-0032-1

Pocknall, D.T., 1980. Modern pollen rain and Aranuian vegetation from Lady Lake, north Westland, New Zealand. New Zealand Journal of Botany 18(2), 275-284. https://doi.org/10.1080/00288 $25 x .1980 .10426925$

Prentice, I.C., Parsons, R.W., 1983. Maximum likelihood linear calibration of pollen spectra in terms of forest composition. Biometrics 39, 1051-1057. https://doi.org/10.2307/2531338

Prentice, I.C., Webb, T III., 1986. Pollen percentages, tree abundances and Fagerland effect. Journal of Quaternary Science 1, 35-43. https://doi. org/10.1002/jqs.3390010105

Quamar, M.F., 2015. Non-pollen palynomorphs from the late Quaternary sediments of southwestern Madhya Pradesh (India) and their palaeoenvironmental implications. Historical Biology 27(8), 10701078. https://doi.org/10.1080/08912963.2014.933212

Quamar, M.F., 2019. Vegetation dynamics in response to climate change from the wetlands of Western Himalaya, India: Holocene Indian Summer Monsoon variability. The Holocene 29(2), 345-362. https://doi.org/10.1177/0959683618810401

Quamar, M.F., 2017. A review on the modern pollen and vegetation relationship studies from eastern Madhya Pradesh, central India. Journal of Geosciences Research (Formerly Gondwana Geological Magazine) 2(1), 17-28.

Quamar, M.F., 2020. Surface pollen distribution from Akhnoor of Jammu District (Jammu and Kashmir), India: implications for the interpretation of fossil 
pollen records. Palynology 44(2), 270-279. https:// doi.org/10.1080/01916122.2019.1568317

Quamar, M.F., Bera, S.K., 2014a. Surface pollen and its relationship with modern vegetation in tropical deciduous forests of southwestern Madhya Pradesh, India: a review. Palynology 38(1), 147161. https://doi.org/10.1080/01916122.2013.875491

Quamar, M.F., Bera, S.K., 2014b. Pollen production and depositional behaviour of teak (Tectona grandis Linn. f.) and sal (Shorea robusta Gaertn. f.) in tropical deciduous forest of Madhya Pradesh (India): An overview. Quaternary International 325, 111-115. https://doi.org/10.1016/j.quaint.2013.07.040

Quamar, M.F., Bera, S.K., 2014c. Evidence of low pollen dispersal efficiency of sal (Shorea robusta Gaertn. f.): Modern pollen rain study from Manendragarh area of Koriya District, Chhattisgarh (India). Journal of Applied Bioscience 40(2), 92-97.

Quamar, M.F., Bera, S.K., 2017. Do the common natural pollen trapping media behave similarly? A comparative study of modern palynoassemblages from Chhattisgarh, central India. Quaternary International 444, 217-226. https://doi.org/10.1016/j. quaint.2016.04.041

Quamar, M.F., Kar, R., 2020. Modern pollen dispersal studies in India: a detailed synthesis and review. Palynology 44(2), 217-236. https://doi.org/10.1080/ 01916122.2018.1557274

Quamar, M.F., Srivastava, J., 2013. Modern pollen rain in relation to vegetation in Jammu, Jammu and Kashmir, India. Journal of Palynology 49, 19-30.

Quamar, M.F., Stivrins, N., 2021. Modern pollen and non-pollen palynomorphs along an altitudinal transect in Jammu and Kashmir (Western Himalaya), India. Palynology (in press). https//:doi.org/10.1080 /01916122.2021.1915402

Quamar, M.F., Ali, S.N., Pandita, S.K., Singh, Y., 2018a. Modern pollen-rain from Udhampur, Jammu and Kashmir, India: insights into pollen production, dispersal, transport and preservation. Palynology 42(1), 55-65. https://doi.org/10.1080/01 916122.2017.1306811

Quamar, M.F., Ali, S.N., Pandita, S.K., Singh, Y., 2018b. Modern pollen assemblages from Reasi (Jammu and Kashmir), India: a tool for interpreting fossil pollen records. Grana 57(5), 364-376. https://doi.org/10.1080/00173134.2018.1478990

Qin, F, Zhao, Y., Li, Q., Cai, M.T., 2015. Modern pollen assemblages from surface lake sediments in northwestern China and their importance as indica-tors of vegetation and climate. Science China: Earth Sciences 58, 1643-1655. https://doi.org/10.1007/ s11430-015-5111-9

Sharma, B.M., Kachroo, P., 1981. Flora of Jammu \& Plants of Neighbourhood. Dehra Dun: Bishen Singh Mahendra Pal Singh.

Sharma, C., Trivedi, A., Malik, A.K., 2001. Modern pollen/spore in Surinsar and Mansar lakes, Jammu. Geophytology 31, 9-17.
Singh, N.P., Singh, D.K., Uniyal, B.P., 2002. Flora of Jammu and Kashmir. Vol. 1. Pteridophytes, Gymnosperms and Angiosperms (Ranunculaceae-Moringaceae). Kolkata: Botanical Survey of India.

Suc, J., Drivaliari, A., 1991. Transport of bisaccate coniferous fossil pollen grains to coastal sediments: an example from the earliest Pliocene Orb Ria (Languedoc, southern France). Review of Palaeobotany and Palynology 70, 247-253. https://doi. org/10.1016/0034-6667(91)90006-o

Sugita, S., 1993. A model of pollen source area for an entire lake surface. Quaternary Research 39, 239244. https://doi.org/10.1006/qres.1993.1027

Sugita, S., 1994. Pollen representation of vegetation in Quaternary sediments: theory and method of patchy vegetation. Journal of Ecology 82, 881-897. https://doi.org/10.2307/2261452

Sugita, S., 2007a. Theory of quantitative reconstruction of vegetation I: pollen from large sites REVEALS regional vegetation composition. The Holocene 17(2), 229-241. https://doi.org/10.1177/0959683607075837

Sugita, S., 2007b. Theory of quantitative reconstruction of vegetation II. All you need is LOVE. The Holocene 17(2), 243-257. https://doi. org/10.1177/0959683607075838

Traverse, A., 2007. Paleopalynology (2nd edn.). The Netherlands: Springer. 813 p.

Van Joolen, E., 2003. Archaeological land evaluation. A reconstruction of the suitability of ancient landscape for various land uses in Italy focused on the first millennium B.C. PhD thesis, University of Groningen.

Vincens, A., Ssemmanda, I., Roux, M., Jolly, D., 1997. Study of modern pollen-rain in western Uganda with a numerical approach. Review of Palaeobotany and Palynology 96, 145-168. https://doi. org/10.1016/s0034-6667(96)00022-x

Vishnu-Mittre, Robert, D.R., 1971. Studies of pollen content of moss cushions in relation to forest composition in the Kashmir valley. Geophytology 1, 84-96.

Wiggs, G.F.S., 1997. Sediment mobilization by the wind. In: Thomas, S., David, G. (eds) Arid Zone Geomorphology. New York: John Wiley and Sons, pp. 351-371.

Wilmshurst, J.M., McGlone, M.S., 2005. Origin of pollen and spores in surface lake sediments: comparison of modern palynomorph assemblages in moss cushions, surface soils and surface lake sediments. Review of Palaeobotany and Palynology 136, 1-15. https://doi.org/10.1016/j.revpalbo.2005.03.007

Xu, Q., Tian, F., Bunting, M.J., Li, Y., Ding, W., Cao, X., He, Z., 2012. Pollen source areas of lakes with inflowing rivers: Modern pollen influx data from Lake Baiyangdian, China. Quaternary Sciences Review 37, 81-91. https://doi.org/10.1016/j. quascirev.2012.01.019 